\title{
初期ひび割れを有するコンクリートの 凍結融解抵抗性に関する基礎的研究
}

\author{
内藤 英樹 1 -林 $\quad$ 弘 2 齊木 $\quad$ 佑介 ${ }^{3}$ ・ 山洞 晃一 4 - 古賀 秀幸 5 - 鈴木 基行 6 \\ 1正会員 東北大学准教授 大学院工学研究科土木工学専攻（=980-8579 仙台市青葉区荒巻字青葉6-6-06） \\ E-mail: naito@civil.tohoku.ac.jp \\ 2松井証券 (株) システムグループ（†102-8516 東京都千代田区靝町1-4 半蔵門ファーストビル6F） \\ 3滑川市＼cjkstart建設部（†936-0806 富山県滑川市北野1085） \\ 4正会員（独）鉄道建設・運輸施設整備支援機構 鉄道建設本部（广030-0801 青森県青森市新町2-2-4） \\ 5正会員（株)オリエンタルコンサルタンツ＼cjkstart東北支店（干984-0065 仙台市若林区土樋104 OC仙台ビル） \\ 6フェロー 東北大学教授 大学院工学研究科土木工学専攻（９980-8579 仙台市青葉区荒巻字青葉6-6-06）
}

模擬ひび割れを導入した無補強コンクリート，繊維補強コンクリート，および鉄筋コンクリート供試体 の凍結融解試験を行った。無補強コンクリートと䋊維補強コンクリートの実験結果より，材料としては高 い凍結融解抵抗性を有するコンクリートを使用した場合でも，模擬ひび割れを導入した供試体では，ひび 割れ部に浸入した水の凍結膨張圧によってひび割れが大きく開口・進展することが示された. その一方で， 繊維長の長いポリプロピレン䋊維は大きなひび割れの開口にも䋊維の架橋を保つことから, コンクリート 片の落下防止の観点からは有用と考えられた。そして, 鉄筋コンクリート供試体の検討では, 軸方向鉄筋 の拘束によって凍結融解に伴うひび割れの進展を大きく抑制できることを確認した.

Key Words : freezing and thawing resistance, fiber reinforced concrete, polypropylene fiber, initial crack

\section{1. はじめに}

寒冷地においてコンクリート構造物の而久性向上を図 るためには，凍結融解抵抗性を確保することが重要課題 の一つとなる．著者ら ${ }^{1)}$ は，北海道新幹線の鉄道構造物 の長期耐久性の確保を目的として，コンクリートの凍結 融解抵抗性に関する研究を行っており，これまでに青森 県の骨材を用いたコンクリートの凍結融解試験を行い, コンクリートの配合 (水セメント比と空気量) と凍結融解 抵抗性 (相対動弾性係数と質量減少率)の関係を整理した. そして，この検討に基づいて，コンクリート標準示方 書 ${ }^{2)}$ に規定される凍結融解抵抗性を満足するコンクリー トの配合条件を示した.

しかし，参考文献 1)に示したコンクリートの配合条 件は，初期欠陥のないコンクリートの凍結融解試験に基 づくものである．実際の構造物では，様々な要因によっ てコンクリート表面に巨視的なひび割れが発生すること があり，寒冷地においてはひび割れ部に浸入した水の凍 結膨張圧によってひび割れが大きく進展する事例も見ら れる ${ }^{3)}$ 。このような損傷は，高架橋の側道や跨道部，跨
線部，トンネル坑口部などのコンクリート片の落下によ る第三者被害を防止すべき箇所においては，特に対策が 必要である。

巨視的なひび割れを有するコンクリートの凍結融解作 用下での損傷に関する研究は, 幾つか報告されている. 橋口ら ${ }^{4)}$ や今村ら ${ }^{5)}$ は, 厚さ $0.1 \mathrm{~mm}$ と $0.3 \mathrm{~mm}$ のステン レス板によって模擬ひび割れを導入した無筋コンクリー 卜供試体の凍結融解試験を行っており, 凍結融解に伴っ てひび割れが大きく進展し，最終的にはひび割れの貫通 によって供試体が分断することを報告している. このと き, 凍結融解サイクルの増加に伴って, 供試体の動弾性 係数が著しく低下している，一方，杉木 ${ }^{9}$ は，ひび割れ 幅 $0.1 〜 0.3 \mathrm{~mm}$ 程度の曲げひび割れを導入した鉄筋コン クリート杭の検討において, 凍結融解に伴うひび割れの 進展が見られないことを報告している。田畑らすも，金 網や鉄線を埋め込んだ鉄筋コンクリート供試体において は，載荷によって貫通ひび割れを導入しても，凍結融解 に伴う顕著な損傷や動弾性係数の低下がないことを報告 している. しかし，このような初期ひび割れの影響に着 目したコンクリートの凍結融解抵抗性に関寸る研究は少 
なく, ひび割れ幅，ひび割れ深さ，コンクリート配合， 繊維や鉄筋による補強の有無などをパラメータとして実 験データを整理した例はない。このため, コンクリート 片の落下を防止すべき箇所において, 凍結融解に伴うひ び割れやコンクリート片の落下を防止する際にも，具体 的な対策の根拠となる実験データが乏しい.

そこで，本研究は，初期ひび割れを有するコンクリー トの凍結融解抵抗性に関する基礎的データを収集するた め, 模擬ひび割れを導入した無補強コンクリート, 繊維 補強コンクリート，および鉄筋コンクリート供試体の凍 結融解試験 (水中凍結水中融解法 : JS A 1148 A 法) を行 った。 なお，これらの供試体は全て $100 \mathrm{~mm} \times 100 \mathrm{~mm} \times$ $400 \mathrm{~mm}$ の角柱供試体としている. はじめに, 無補強コ ンクリート供試体を用いて, ひび割れ幅, ひび割れ深さ およびコンクリート配合が凍結融解に伴うひび割れ進展 性状に及ぼす影響を検討する。

次に, 䋊維補強コンクリートのひび割れ進展性状を検 討する. 近年, トンネルや高架橋におけるコンクリート 片の落下事故が大きな社会問題となっており, ポリプロ ピレン繊維 (以下，PP 繊維) を混入したコンクリート片 の落下防止が検討されている ${ }^{8) 111}$. このような䋊維補強 コンクリートは, 繊維の架橋によってコンクリート片の 落下防止を期待するものであり，ハンマーを用いた打撃 試験 ${ }^{9)}$ (衝撃試験) によってコンクリート片の落下防止効 果が確認されている。しかし，ひび割れ部に繰返し凍結 融解を受けた繊維補強コンクリートの引張特性を検討し た例は著者らが知る限りなく, 凍結融解に起因するひび 割れ進展やコンクリート片の落下防止に対する PP 繊維 の効果は明らかではない.すでに寒冷地の鉄道構造物な どにおいても PP 繊維が多く使用されており, 耐衝撃性 と併せて凍結融解に伴うコンクリート片の落下防止効果 が確認できれば，寒冷地におけるコンクリート構造物の 長期耐久性の向上にも有用である，そこで，本研究では， 3 種類のポリプロピレン繊維と, 比較として 1 種類の鋼 繊維を用いた繊維補強コンクリートの凍結融解試験を実 施する.

そして，かぶりと鉄筋径をパラメータとした鉄筋コン クリート供試体の検討も行った．参考文献 6),7)を参照 する限りでは，鉄筋の拘束によって凍結融解に伴うひび 割れの進展が効果的に抑制されることが予想される. 本 研究では, 前記の無補強コンクリートや繊維補強コンク リートと同じコンクリート配合，供試体諸元，実験条件 での凍結融解試験結果を比較することにより，鉄筋の補 強効果を実験的に示寸，なお，実験データの一部 ${ }^{12-14}$ は 既に報告しているが，本研究ではこれらの一連の凍結融 解試験も含めて, 寒冷地におけるコンクリート片の落下 防止対策について考察する.
表-1 凍結融解試験の供試体諸元一覧

(a) 無補強コンクリート供試体

\begin{tabular}{|c|c|c|c|c|}
\hline 供試体名※ & 本数 & $\begin{array}{l}\text { コンク } \\
\text { リート } \\
\text { 配合 }\end{array}$ & $\begin{array}{c}\text { 初期ひび } \\
\text { 割れ幅 } \\
\text { (mm) }\end{array}$ & $\begin{array}{c}\text { 初期ひび } \\
\text { 割れ深さ } \\
\text { (mm) }\end{array}$ \\
\hline Base1-N & 3 & \multirow{5}{*}{ Base 1} & - & - \\
\hline Base1-cr10 & 3 & & 0.3 & 10 \\
\hline Base1-cr30 & 9 & & 0.3 & 30 \\
\hline Base1-cr50 & 3 & & 0.3 & 50 \\
\hline Base1-cr30(0.1) & 3 & & 0.1 & 30 \\
\hline Base2-N & 3 & \multirow{2}{*}{ Base 2} & - & - \\
\hline Base2-cr & 3 & & 0.3 & 30 \\
\hline
\end{tabular}

※ H19 年に各シリーズ 3 体を実施した. H21 年と H22 年に Base1-cr30をそれぞれ3体実施した。

(b) 䋊維補強コンクリート供試体

\begin{tabular}{|c|c|c|c|c|c|}
\hline 供試体名 & 本数 & $\begin{array}{l}\text { コンク } \\
\text { リート } \\
\text { 配合 }\end{array}$ & $\begin{array}{l}\text { 繊維 } \\
\text { 種別 }\end{array}$ & $\begin{array}{c}\text { 繊維の体 } \\
\text { 積混入率 } \\
(\%)\end{array}$ & $\begin{array}{l}\text { ひび割れ } \\
\text { の有無※3 }\end{array}$ \\
\hline PP1-N※1 & 3 & \multirow{4}{*}{ Base 1} & \multirow{2}{*}{ PP1 } & \multirow{2}{*}{0.05} & なし \\
\hline PP1-cr ${ }^{※ 1}$ & 3 & & & & あり \\
\hline PP2-N※1 & 3 & & \multirow{2}{*}{ PP2 } & \multirow{2}{*}{0.10} & なし \\
\hline PP2-cr ${ }^{\star 1}$ & 3 & & & & あり \\
\hline PP3-N※2 & 3 & \multirow{4}{*}{ Base 2} & \multirow{2}{*}{ PP3 } & \multirow{2}{*}{0.50} & なし \\
\hline PР3-C ${ }^{* 2}$ & 3 & & & & あり \\
\hline Steel-N※2 & 3 & & \multirow{2}{*}{ Steel } & \multirow{2}{*}{0.50} & なし \\
\hline Steel-cr ${ }^{\star 2}$ & 3 & & & & あり \\
\hline
\end{tabular}

$※ 1:$ H20年に実施した. $※ 2: H 21$ 年に実施した。

$※ 3$ : 初期ひひ搳れ幅 $0.3 \mathrm{~mm}$, 初期ひひ割れ深さ $30 \mathrm{~mm}$ とした.

(c) 鉄筋コンクリート供試体

\begin{tabular}{|c|c|c|c|c|}
\hline 供試体名※1 & 本数 & 鉄筋径 & $\begin{array}{c}\text { 打設面から鉄筋 } \\
\text { 中心位置までの } \\
\text { 距離(mm) }\end{array}$ & $\begin{array}{l}\text { ひび割れ } \\
\text { の有無※2 }\end{array}$ \\
\hline D6-N & 3 & \multirow{3}{*}{ D6 } & \multirow{2}{*}{50} & なし \\
\hline D6-cr & 3 & & & あり \\
\hline D6-ar(70) & 3 & & 70 & あり \\
\hline D10-N & 3 & \multirow{2}{*}{ D10 } & \multirow{2}{*}{50} & なし \\
\hline D10-cr & 3 & & & あり \\
\hline
\end{tabular}

※1: H22年に各シリーズ3体を実施した。

※2 : 初期ひひ割れ幅 $0.3 \mathrm{~mm}$, 初期ひび割れ深さ $30 \mathrm{~mm}$ とする。

\section{2. 無補強コンクリート}

\section{(1) 実験概要}

供試体諸元およびコンクリートの示方配合を表ー1 (a) および表-2 に示す，供試体概略図を図一1 に示寸。供 
表一2 コンクリートの示方配合

\begin{tabular}{|c|c|c|c|c|c|c|c|c|c|c|}
\hline \multirow[b]{2}{*}{ 配合名 } & \multirow{2}{*}{$\begin{array}{c}\text { 粗骨材 } \\
\text { の最大 } \\
\text { 寸法 } \\
(\mathrm{mm})\end{array}$} & \multirow{2}{*}{$\begin{array}{l}\text { スラ } \\
\text { ンプ } \\
\\
\text { (cm) }\end{array}$} & \multirow{2}{*}{$\begin{array}{l}\text { 水セメ } \\
\text { ント比 } \\
\text { W/C } \\
(\%)\end{array}$} & \multirow[b]{2}{*}{$\begin{array}{c}\text { 空気量 } \\
\text { (\%) }\end{array}$} & \multirow[b]{2}{*}{$\begin{array}{c}\text { 細骨 } \\
\text { 材率 } \\
\text { s/a } \\
\text { (\%) }\end{array}$} & \multicolumn{5}{|c|}{ 単位量 $\left(\mathrm{kg} / \mathrm{m}^{3}\right)$} \\
\hline & & & & & & $\begin{array}{l}\text { 水 } \\
\mathrm{W}\end{array}$ & $\begin{array}{c}\text { セメント } \\
\text { C }\end{array}$ & $\begin{array}{c}\text { 細骨材 } ※ 3 \\
\text { S }\end{array}$ & $\begin{array}{c}\text { 粗骨材※3 } \\
\text { G }\end{array}$ & $\begin{array}{c}\mathrm{AE} \\
\text { 減水剂 } \\
\mathrm{A}\end{array}$ \\
\hline Base $1 \% 1$ & 25 & $8 \pm 2.5$ & 53 & $5.5 \pm 0.25$ & 40.6 & 148 & 279 & 755 & 1143 & 2.790 \\
\hline Base $2{ }^{* 2}$ & 25 & 15 & 51 & $5.5 \pm 0.5$ & 50.7 & 173 & 339 & 875 & 889 & 4.068 \\
\hline
\end{tabular}

※1 : Base1配合では，バイブレータによる締め固め後の状態に対して，空気量とスランプを管理した ${ }^{11}$.

※2 : Base2配合では，突き棒による締め固め後の状態に対して，空気量のみを管理した.

$※ 3$ : Base 1 配合は, 山砂 $599 \mathrm{~kg} / \mathrm{m}^{3}$, 砕砂 $156 \mathrm{~kg} / \mathrm{m}^{3}$, 粗骨材 A $570 \mathrm{~kg} / \mathrm{m}^{3}$, 粗骨材 B $573 \mathrm{~kg} / \mathrm{m}^{3}$ を使用した.

Base 2配合は，山砂 $697 \mathrm{~kg} / \mathrm{m}^{3}$ ，砕砂 $178 \mathrm{~kg} / \mathrm{m}^{3}$ ，粗骨材 B $889 \mathrm{~kg} / \mathrm{m}^{3}$ を使用した.

山砂 (天然山砂) : 表乾密度 $2.58 \mathrm{~g} / \mathrm{cm}^{3}$, 吸水率 $1.6 \%$

粗骨材 A (石灰石) : 表乾密度 $2.70 \mathrm{~g} / \mathrm{cm}^{3}$, 吸水率 $1.1 \%$

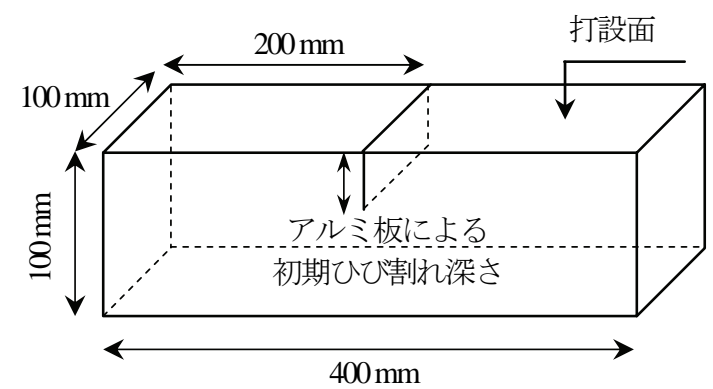

図-1 供試体の概略図

試体寸法は $100 \mathrm{~mm} \times 100 \mathrm{~mm} \times 400 \mathrm{~mm}$ の角柱とし，セメ ントは普通ポルトランドセメントを使用した，本検討で

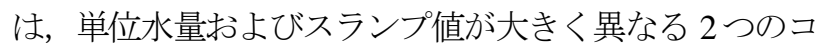
ンクリート配合を用いており，Base 1 と Base 2 のコンク リート配合は，後述する繊維補強コンクリートや鉄筋コ ンクリート供試体の検討でも使用している．Base 1 は参 考文献 1)に示した $\mathrm{AE}$ コンクリートの基準配合であり，

Base 2 は鉄道構造物の施工実績を参考にした。本研究は, 初期ひび割れがコンクリートの凍結融解抵抗性に及ぼす 影響を検討するため，図一1に示すように，打設時にア ルミ板を埋め込むことによって模擬ひび割れを導入した 供試体 (以下，ひび割れ供試体)を作製する. 鉄道構造物 の設計規準 ${ }^{15}$ に示される許容ひび割れ幅を参考にして, アルミ板の厚さは $0.3 \mathrm{~mm}$ を基準とした. さらに, 橋口 ら ${ }^{4}$ の研究を参考にして, ひび割れ深さは $30 \mathrm{~mm}$ を基準 とした．表一1(a)のように，実験パラメータは，コンク リート配合 (Base1, Base 2)，ひび割れ幅 $(0.1,0.3 \mathrm{~mm})$, ひ び割れ深さ $(10,30,50 \mathrm{~mm})$ とした. 供試体数はそれぞれ 3 体を基本としているが，供試体ごとの実験結果のばらつ きを検討するため, Base1-cr30 は供試体数を 9 体とした。

模擬ひび割れの導入は，図一1 に示寸ように，コンク リートを打設する際にグリースを塗布した幅 $100 \mathrm{~mm} の$ アルミ板を供試体打設面の中央位置に垂直に埋め込み, 打設から 3〜4 時間後にアルミ板を引き抜いた ${ }^{4}$. アアル ミ板は，市販のものを金属用カッターを用いて周辺部か
砕砂 (玄武岩質安山岩) : 表乾密度 $2.68 \mathrm{~g} / \mathrm{cm}^{3}$, 吸水率 $2.3 \%$

粗骨材 B (玄武岩質安山岩) : 表乾密度 $2.71 \mathrm{~g} / \mathrm{cm}^{3}$, 吸水率 $1.1 \%$

表-3 実験室内の気温と相対湿度

(a) H19年供試体

\begin{tabular}{c|c|c|c|c|c|c}
\hline & 打設日 & 1 日 & 2 日 & 3 日 & 4 日 & 日 日 \\
\hline 温度 $\left({ }^{\circ} \mathrm{C}\right)$ & 28 & 27 & 26 & 27 & 27 & 28 \\
\hline 湿度 $(\%)$ & 58 & 72 & 72 & 67 & 67 & 68 \\
\hline
\end{tabular}

(b) $\mathrm{H} 20$ 年供試体

\begin{tabular}{c|c|c|c|c|c|c}
\hline & 打設日 & 1 日 & 2 日 & 3 日 & 4 日 & 5 日 \\
\hline 温度 $\left({ }^{\circ} \mathrm{C}\right)$ & 20 & 24 & 27 & - & 29 & 29 \\
\hline 湿度 $(\%)$ & 58 & 70 & 50 & - & 59 & 55 \\
\hline
\end{tabular}

(c) $\mathrm{H} 21$ 年供試体

\begin{tabular}{c|c|c|c|c|c|c}
\hline & 打設日 & 1 日 & 2 日 & 3 日 & 4 日 & 5 日 \\
\hline 温度 $\left({ }^{\circ} \mathrm{C}\right)$ & 24 & 26 & 26 & - & 22 & 23 \\
\hline 湿度(\%) & 79 & 79 & 79 & - & 63 & 79 \\
\hline
\end{tabular}

(d) $\mathrm{H} 22$ 年供試体

\begin{tabular}{c|c|c|c|c|c|c}
\hline & 打設日 & 1 日 & 2 日 & 3 日 & 4 日 & 日 \\
\hline 温度 $\left({ }^{\circ} \mathrm{C}\right)$ & 29 & 28 & - & - & - & - \\
\hline 湿度(\%) & 68 & 76 & - & - & - & - \\
\hline
\end{tabular}

※温度と湿度は，9, 12, 17 時の測定值の平均を示した。

ら $100 \mathrm{~mm} \times 100 \mathrm{~mm}$ の矩形板に切り出し, カッターによ る切断面がひび割れ先端にならないように配置した. 目 視による観察の範囲では，コンクリート打設の前後でも アルミ板の平面度は保たれており, 大きな変形は生じて いない，なお，ひび割れ供試体の作製では，ひび割れ部 や打設面の処理は特に行っていない. 打設後は，鉄道構 造物の施工を想定して，気温や湿度を調整せずに実験室 内に 5 日間型枠を設置し，その後の材齢 28 日まで実験 室内に気中静置した。打設から 5 日間の実験室の気温と 相対湿度を表一3 に示す。試験開始前の 3 日間は，この 実験室内において水を満たした容器内に供試体を静置し， 水を含ませた状態を基準として質量減少率を計測した.

凍結融解試験は水中凍結水中融解法 (JIS A 1148 A 法) として, 供試体中心部の温度が $-18 \sim+5^{\circ} \mathrm{C}$ に変化する ように，300 サイクルの温度履歴を与えた ${ }^{10}$. 別途作製 


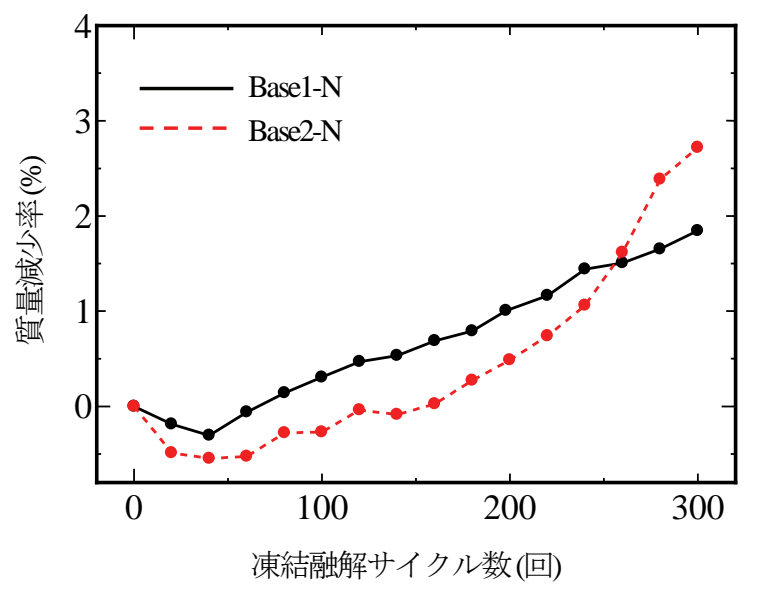

図－2＼cjkstart無補強コンクリートの質量減少率

したテストピース $(\phi 100 \mathrm{~mm} \times 200 \mathrm{~mm})$ による試験開始時 (材齢 28 日) の圧縮強度試験の結果は，Base1配合が 33.5 MPa，Base 2配合が 41.1 MPaであった。

\section{(2) 質量減少率および相対動弾性係数}

ひび割れのない供試体について，20 サイクル毎の質 量減少率と相対動弾性係数をそれぞれ図-2 と図一3に 示す。これらは，供試体シリーズごとの平均值を示した。 本実験のひび割れを導入した供試体では，たわみ振動よ りも縦振動計測の方が，ひび割れの進展が大きい場合に も共鳴振動数を妥当に評価することができた ${ }^{17)}$. そこで, JIS A 1127 に準じて, 共鳴振動試験 (縦振動) により動弾 性係数を評価した ${ }^{16)}$.

$$
E_{D}=4.00 \times 10^{-3} \frac{L}{A} m f^{2}
$$

ここで， $E_{D}$ は動弾性係数(MPa)，L は供試体の長さ (mm), $A$ は供試体の断面積 $\left(\mathrm{mm}^{2}\right), \quad m$ は供試体の質量 $(\mathrm{kg}), f$ は 縦振動の一次共鳴振動数 $(\mathrm{Hz})$ である.

図ー2 より，Base 1-N および Base 2-N 供試体の 300 サ イクル時の質量減少率は 2〜3\%程度であり，目視で確 認する限り，両者のコンクリート表面の損傷状況には大 きな差異はなかった。 なお, 図一2 の質量減少率では, 40～60 サイクル程度まで吸水による質量の増加が見ら れ，図一3 の相対動弾性係数にも水和反応と考えられる 硬化が確認された，後述する実験データも含めて水和反 応の影響を除去していない結果ではあるが，図一3 に示 すように，ひび割れを導入しない Base 1-Nおよび Base2$\mathrm{N}$ 供試体の動弾性係数の変化より，表一2 に示すコンク リート配合 (Base1, Base2) はいずれも凍結融解抵抗性の 高い AEコンクリートであると考えられる.

\section{(3) ひび割れ深さ}

模擬ひび割れを導入した Base1-cr30 や Base 2-cr 供試体

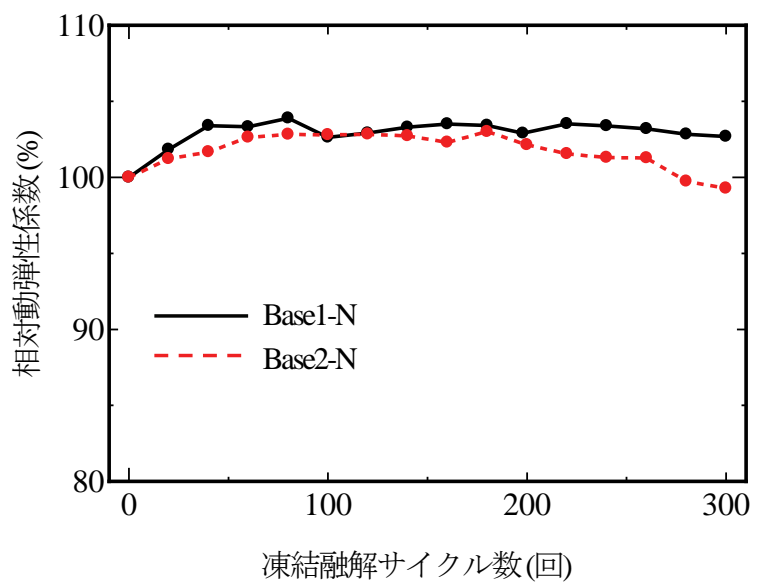

図－3＼cjkstart無補強コンクリートの相対動弾性係数

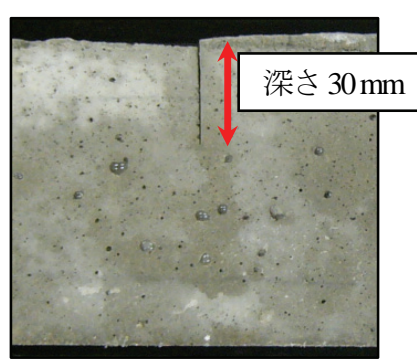

縦振動による共鳴振動数

0サイクル : $4610 \mathrm{~Hz}$

77 サイクル : $3057 \mathrm{~Hz}$

100 サイクル : 測定不可

※ひび割れのない供試体

(Base1-N)の 0 サイクル時

の共鳴振動数 : $4993 \mathrm{~Hz}$

0サイクル

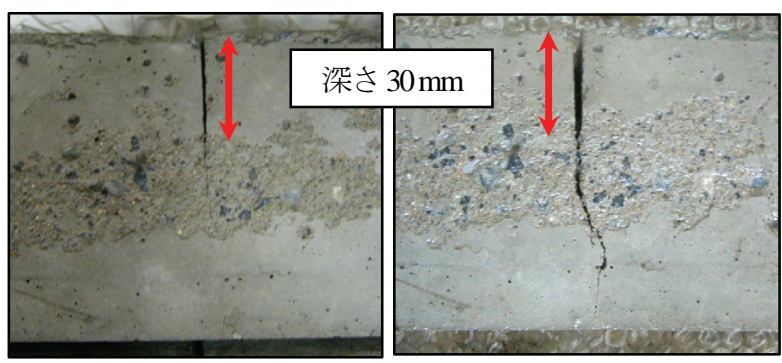

77サイクル

100 サイクル

(a) 供試体側面のひび割れ進展状況

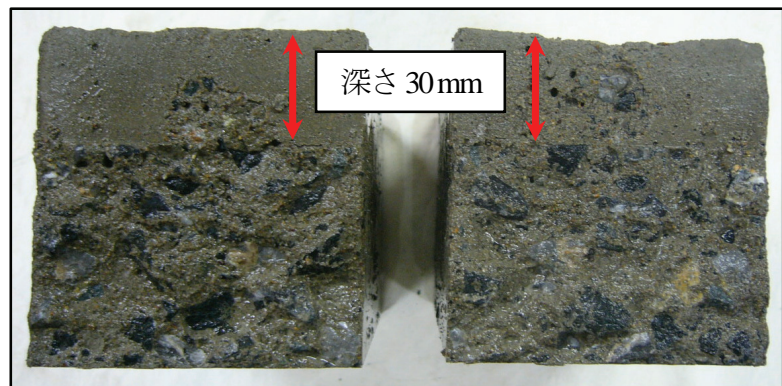

(b) 破断面 (100サイクル)

写真-1 Base1-cr30供試体の損傷状況

では，供試体ごとの損傷程度が大きくばらついたが，凍 結融解サイクル数の増加に伴ってひび割れの進展が目視 でも確認された．ひび割れ供試体の損傷状況の一例を写 真-1 に示寸. 写真-1(a)に示寸ように，供試体の側面 から凍結融解に伴うひび割れの進展が目視によって確認 
できた.これは，ひび割れ部に浸入した水の凍結膨張圧 によってひび割れが開口したものと推察される ${ }^{4)}$.さら に, ひび割れの進展に伴って共鳴振動数も低下した. 写 真-1 の損傷状況や，図-2 と図-3 のひび割れの無い 供試体の実験結果から, 共鳴振動数が低下寸る要因は材 料劣化によるものでなく, 巨視的なひび割れの進展に起 因していると考えられる.

凍結融解サイクル数とひび割れ深さの関係を整理する. 供試体の側面に現れるひび割れの先端は極めて小さく， 目視によってひび割れ深さを正確に計測することは容易 ではない，そこで，著者ら ${ }^{13,17}$ は，ひび割れの進展に伴 って供試体の一次共鳴振動数が低下寸ることに着目して, 共鳴振動試験に基づくひび割れ深さ推定式を提示した. ひび割れ深さ推定式は，図ー1に対してひび割れ梁さと FEM 解析 (固有值解析) から得られる一次共鳴振動数之 の関係を回帰することによって得た．解析条件などの詳 細は，参考文献 13),17)に示した. 式(2)のひび割れ深さ と共鳴振動数との関係を図ー4に示す.

$$
d=100-97.161\left(\frac{f}{f_{0}}\right)^{3.633}
$$

ここで，fは縦振動による一次共鳴振動数 $(\mathrm{Hz}), d$ はひび 割れ深さ $(\mathrm{mm}), f_{0}$ はひび割れがない供試体の共鳴振動 数 $(\mathrm{Hz})$ である. ただし, 式(2)は図一1に示すように, アルミ板による模擬ひび割れを想定した FEM 解析に基 づく評価式であり，実際のひび割れに見られる微細な先 端形状や骨材のかみ合わせなどを考慮したものではなく, 奥行き方向のひび割れ深さを一様と仮定した．また，式 (2) は $100 \mathrm{~mm} \times 100 \mathrm{~mm} \times 400 \mathrm{~mm}$ の角柱供試体に対しての み適用可能である.

角柱供試体 60 体 ${ }^{13,17)}$ の共鳴振動試験上り得られる共 鳴振動数 $f$ とひび割れ深さ $d$ との関係を図一 4 に併せて 示す．ここでは， 60 体の供試体には凍結融解を与えず に, 式(2)による初期ひび割れ深さの推定精度を検討し ている. 以降では, 共鳴振動数に着目して, 式(2)によ って供試体のひび割れ深さを推定する.

無補強コンクリート供試体について, 凍結融解サイク ル数とひび割れ深さの推定值の関係を図一5に示寸. 供 試体ごとのばらつきが大きい実験結果ではあるが，初期 ひび割れ深さを変化させた Base1-cr10, Base1-cr30, Base1cr50 の比較では, 初期ひび割れ深さが大きいほど 300 サ イクルまでにひび割れが貫通して供試体が分断する割合 が多い. なお， Base1-cr10 のように初期ひび割れ深さが 小さくても, 最終的には供試体が分断する供試体も見ら れた．また，ひび割れ幅 $0.1 \mathrm{~mm} の$ Base 1-cr30 (0.1) 供試体 でもひび割れが進展するものが見られ，ひび割れ幅 (0.1, $0.3 \mathrm{~mm})$ による明確な差異は見出せなかった. 以上より, 材料としては高い凍結融解抵抗性を有するコンクリート

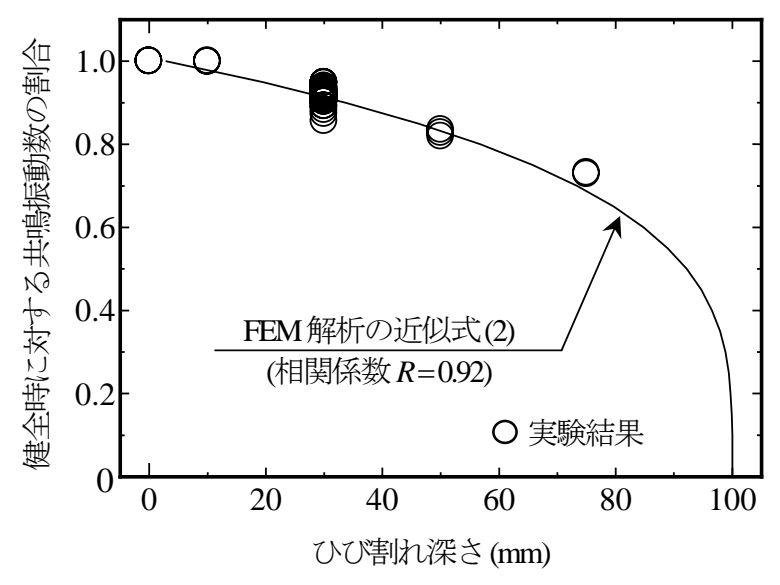

図-4 ひび割れ深さと共鳴振動数の関係 ${ }^{13,17)}$

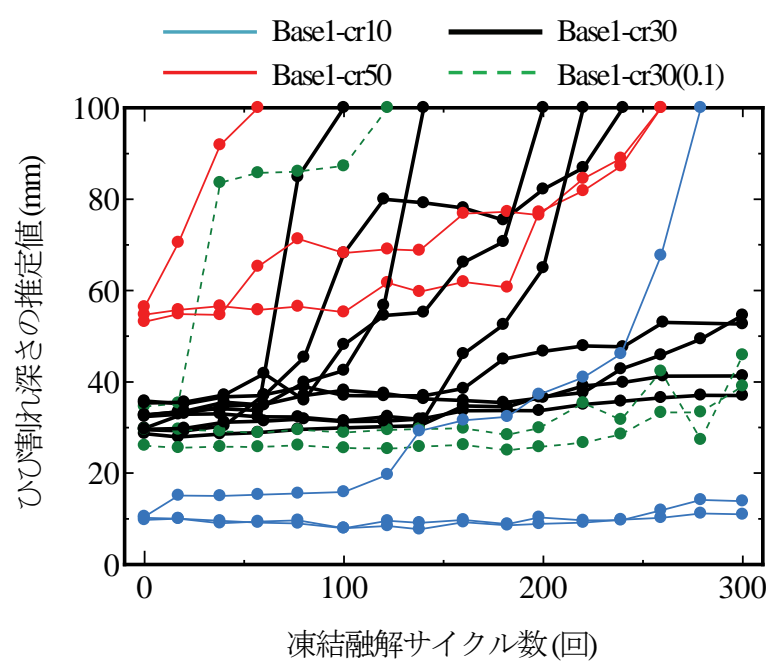

図－5＼cjkstart無補強コンクリートのひび割れ深さ

であっても，わずかな初期ひび割れが存在し，水の供給 がある箇所においては, 凍結融解に伴うひび割れの進展 が顕在化する可能性が示唆された。

Base2_cr供試体でも，3体の供試体がそれぞれ 40, 100， 120 サイクルまでにひび割れが貫通して供試体が分断し た ${ }^{14}$. Base1_crや Base2_cr供試体および後述するひび割 れ供試体において，各シリーズの中でも供試体ごとのば らつきが大きく表れた．ひび割れ先端の形状や骨材との 位置関係，および骨材とセメント界面の特性などによっ て実験結果が大きくばらつくと考えられたが，本実験の 条件および計測の範囲ではその理由を明らかにすること はできなかった. 今後, さらに多くの実験デー夕を収集 し，メカニズムの面からも検討する必要がある.

\section{3. 䋊維補強コンクリート}

\section{（1）凍結融解試験}

\section{a) 実験概要}

繊維補強コンクリートの供試体諸元を表一1(b)に示寸. 
表一4 繊維の特性

\begin{tabular}{|c|c|c|c|c|c|c|c|}
\hline 繊維名 & $\begin{array}{l}\text { 標準体積 } \\
\text { 混入率(\%) }\end{array}$ & $\begin{array}{l}\text { 長さ } \\
(\mathrm{mm})\end{array}$ & $\begin{array}{c}\text { 換算直径 } \\
(\mu \mathrm{m})\end{array}$ & $\begin{array}{c}\text { 比重 } \\
\left(\mathrm{g} / \mathrm{cm}^{3}\right)\end{array}$ & $\begin{array}{c}\text { ヤング係数 } \\
\text { (MPa) }\end{array}$ & $\begin{array}{c}\text { 引張強度 } \\
\text { (MPa) }\end{array}$ & 繊維形状 \\
\hline PP1繊維 & 0.05 & 12 & 64.8 & 0.91 & 5000 & 530 & 単繊維 \\
\hline PP2繊維 & 0.10 & 12 & 300 & 0.91 & 4000 & 670 & 網目状䋊維 \\
\hline PP3繊維 & 0.50 & 48 & 680 & 0.91 & - & 500 & 単繊維 (X断面) \\
\hline Steel 繊維 & 0.50 & 40 & 900 & 7.85 & - & 980 & フック型※ \\
\hline
\end{tabular}

※ Steel繊維の形状 :

表－5 繊維補強コンクリートのスランプ值，空気量，および強度試験の結果

\begin{tabular}{c||c|c||c|c|c||c}
\hline 供試体名 & $\begin{array}{c}\text { スランプ值 } \\
(\mathrm{cm})\end{array}$ & $\begin{array}{c}\text { 空気量 } \\
(\%)\end{array}$ & $\begin{array}{c}\text { 圧縮強度 } \\
(\mathrm{MPa})\end{array}$ & $\begin{array}{c}\text { 引張強度 } \\
(\mathrm{MPa})\end{array}$ & $\begin{array}{c}\text { 静弾性係数 } \\
(\mathrm{MPa})\end{array}$ & $\begin{array}{c}\text { 動弾性係数 } \\
(\mathrm{MPa})\end{array}$ \\
\hline \hline Base1-N & 10.0 & 6.3 & 33.5 & 2.03 & 21800 & 36600 \\
\hline PP1-N & 8.0 & 6.0 & 31.8 & 2.25 & 21600 & 35000 \\
\hline PP2-N & 9.5 & 8.2 & 29.1 & 1.89 & 20000 & 34300 \\
\hline Base2-N & 21.5 & 5.5 & 41.1 & 3.17 & 23600 & 34900 \\
\hline PP3-N & 15.5 & 6.2 & 40.4 & 3.20 & 22700 & 33800 \\
\hline Steel-N & 20.5 & 6.4 & 39.2 & 3.40 & 24200 & 34800 \\
\hline
\end{tabular}

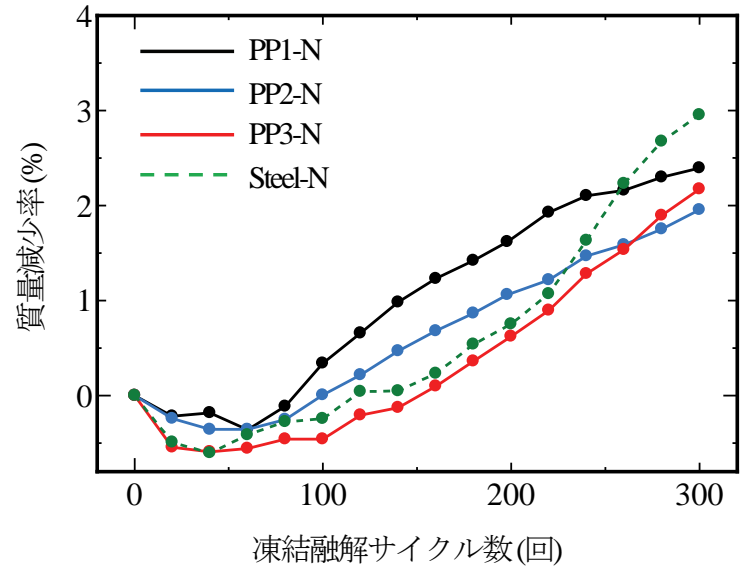

図一6＼cjkstart繊維補強コンクリートの質量減少率

本研究では，表一4に示寸 3 種類のポリプロピレン繊維 (PP1, PP2, PP3) と，比較として 1 種類の鋼䋊維 (Steel) を検 討する. PP1 繊維と PP2 䋊維は繊維長が短く, 繊維形状 (単繊維, 網目状繊維) とアスペクト比が異なる 2 種類を 選定した．これらのコンクリート配合は，表一2 に示し た Base1配合に繊維を混入した．また，大きなひび割れ の開口に対しても繊維の架橋が保たれることを期待して, 繊維長の長いPP3繊維を選定した. 繊維長の長いポリプ ロピレン䋊維を使用した場合には，スランプが大きく低 下寸るため，PP3繊維や Steel䋊維では単位水量が大きい コンクリート配合として，表一2 の Base 2 配合に繊維を 混入した. 表一1(b) や表一4 に示寸体積混入量は，施工 性やハンマーによる打撃試験 (而衝撃性)に基づいて定め

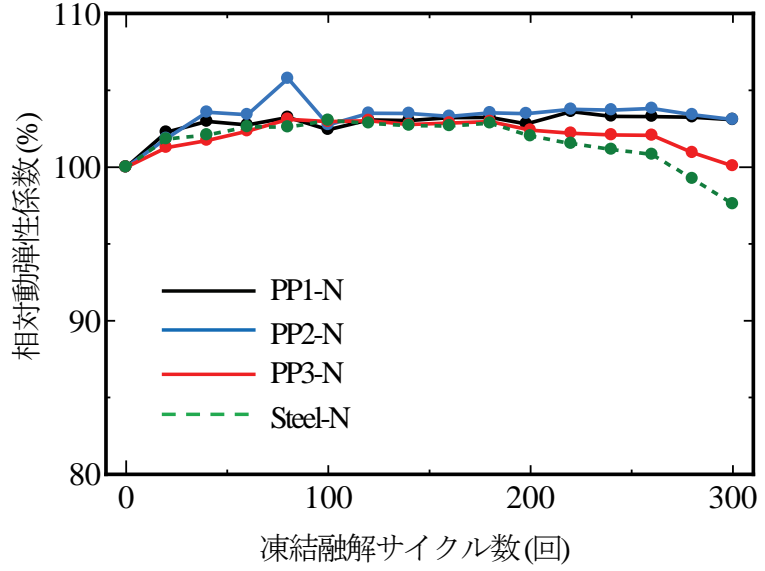

図-7 繊維補強コンクリートの相対動弾性係数

られたそれぞれの繊維の標淮体積混入量である.

模擬ひび割れの導入や涷結融解試験の方法などは, 前 記の無補強コンクリート供試体と同様である.

\section{b) 材料試験}

フレッシュコンクリートのスランプと空気量を表 -5 に示す。ここに示す空気量は，いずれも突き棒による締 め固め後の值である. 䋊維長が長い PP3 䋊維を混入する ことによってスランプが大きく低下した．一方，PP1 纎 維，PP2 繊維，Steel 繊維を混入してもスランプはほとん ど低下しなかった．表一5 に示寸空気量より，PP2 繊維 (網目状繊維) は空気が付着しや寸く, 繊維混入量の増加 とともにコンクリート中のエントラップドエアが増加し たと推察される.これに対して, PP1, PP3, Steel繊維はい 


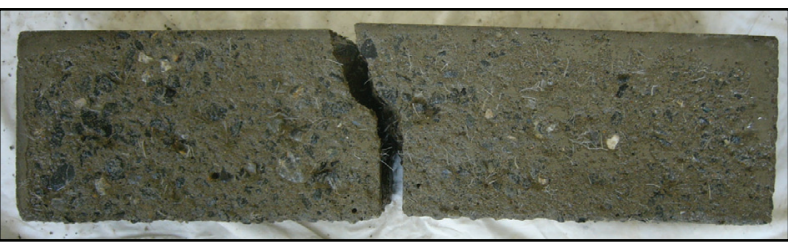

(a) 割裂状況 (側面) (PP1-cr : 240サイクル)

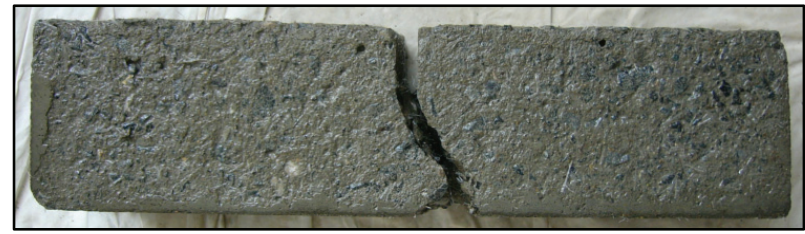

(b) 割裂状況 (側面) (PP2-cr：198サイクル)

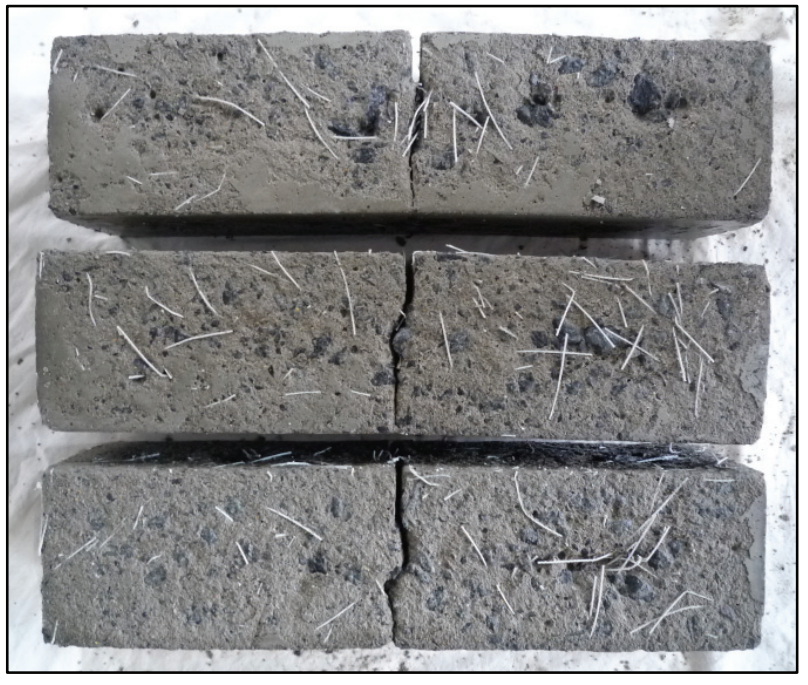

(c) 割裂状況 (側面) (PP3-cr : 300サイクル)

写真－2 繊維補強コンクリートの損傷状況

ずれも単繊維であり，䋊維混入量による空気量の変化は PP2 䋊維と比較して小さかった.

材齢 28 日における強度試験の結果を表一5に併せて 示寸．空気量が大きい PP2 試験体では Base 1 試験体に 対して圧縮強度や引張強度が若干低下したが，PP1， PP3, Steel 試験体では繊維の混入による圧縮強度, 引張 強度, 静弾性係数および動弾性係数に大きな変化はな かった.

\section{c) 質量減少率および相対動弾性係数}

ひび割れのない繊維補強コンクリートの質量減少率お よび相対動弾性係数をそれぞれ図ー6 および図ー7 に示 す。これらの実験結果は, 供試体シリーズごとの平均值 を示した. 図一6より，300 サイクルでも質量減少率は 2〜3\%程度であり, 図一2 に示した Base1-N や Base 2-N と比較して, 繊維の混入が質量減少率に及ぼす影響は小 さかった。 なお，コンクリート表面の損傷状況について も, 繊維混入の有無や繊維種別による顕著な差異はなか った. 図一7より，ひび割れのない 4 種類の繊維補強コ ンクリートでも水和による硬化が見られ，動弾性係数の 低下は小さかった。

\section{d) ひび割れ深さ}

繊維補強コンクリートを用いても，ひび割れ供試体で は, 凍結融解サイクル数の増加とともにひび割れが進展 した. 前記の無補強コンクリートと同様に, これらは同 じ条件で作製した 3 体の供試体であっても，ひび割れの 進展や共鳴振動数の低下は大きくばらついた. 各供試体 の損傷状況を写真－2 に示す． 20 サイクル毎の共鳴振動 試験の結果を式(2)に代入することによって得られるひ び割れ深さの推定值を図ー8 に示す. 図一 8 より，4 種 類のいずれの䋊維補強コンクリートでも，凍結融解に伴 うひび割れの進展を防ぐことはできなかった．特に，

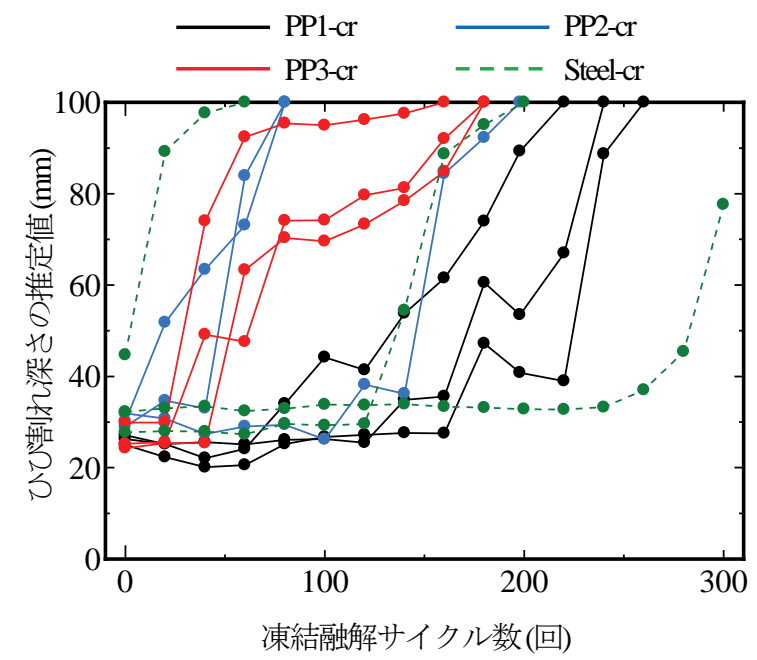

図－8＼cjkstart繊維補強コンクリートのひび割れ深さ

Base 1 配合を用いた PP1-cr や PP2-cr では, 図一5 に示し た無補強コンクリート (Baes1-cr30) よりも 300 サイクル までにひび割れが貫通する供試体の割合が多い，PP1， PP2, PP3 繊維は，ハンマーを用いた打撃試験 (衝撃試験) によってコンクリート片の落下防止効果が確認されてい るが，凍結融解に着目した本検討においては，3 種類の ポリプロピレン繊維によるひび割れ抑制効果は得られな かった．また，鋼繊維を混入した Steel-cr 供試体でも， 300 サイクルまでひび割れの進展を抑制できなかった.

しかし，写真一2(a),(b) に示寸ように繊維長の短い PP1-cr と PP2-cr 供試体では，ひび割れの進展によって供 試体が分断したが，写真一2(c)に示寸繊維長の長い PP3Cr 供試体では，ひび割れ貫通後も繊維がひび割れを跨い で架橋しており，写真一3に示寸ように 300 サイクル後 のひび割れが大きく開口した状態であっても，コンクリ 
ート片が落下寸ることはなかった，すなわち，PP3 繊維 はひび割れの進展は防げないが，コンクリート片の落下 防止に対しては有用と考えられる，なお，鋼䋊維を混入 した Steel-cr 供試体でも，ひび割れの貫通と同時に供試 体が分断することはなかったが，300 サイクルまで涷結 融解を与えた結果, 䋊維の架橋による引張抵抗力は失わ れており，供試体は容易に分断した．繊維長が長い鋼繊 維であっても，ひび割れ面に凍結融解を受ける中でコン クリートと繊維の付着を強固に維持できない限り，コン クリート片の落下防止は期待できないと考えられる.

以上より, 繊維補強コンクリートの検討では, 繊維長 が長い PP3繊維を使用した場合のみ,ひひ割れによって 供試体が分断することはなかった. 以降では，300 サイ クルの凍結融解試験を終えた 3 体の PP3-cr 供試体の曲げ 載荷試験を行い，繊維の架橋によるひび割れ面の引張特 性を検討する. さらに, 解析的検討を加え, 䋊維単体の 引抜強度を同定する。

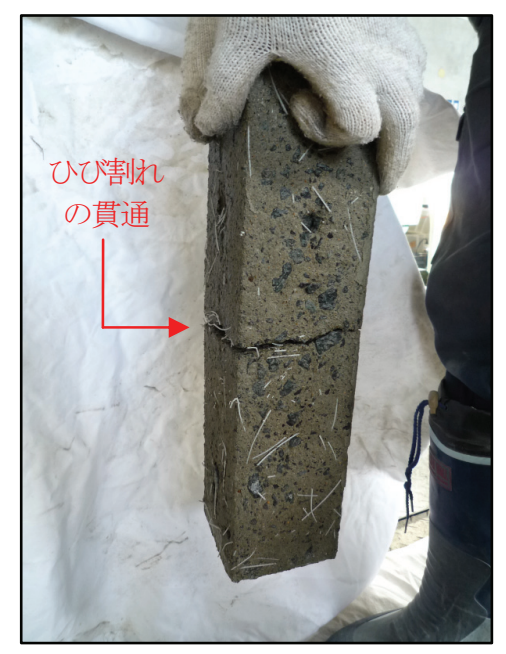

PP3-cr 供試体 (300サイクル)

写真-3 コンクリート片の落下防止効果 (PP3 繊維)

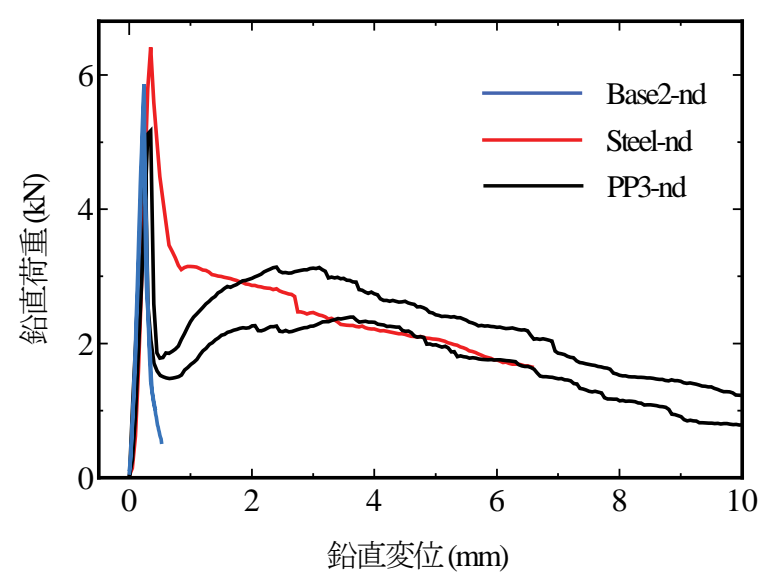

図-9 健全供試体の曲げ載荷試験

\section{（2）曲げ載荷試験}

\section{a) 実験概要}

図－8 に示すように，PP3-cr 供試体はいずれも160〜 180 サイクルにひび割れが供試体を貫通したが，その後 も 300 サイクルまで凍結融解を与え続けた. 曲げ載荷試 験に用いる供試体の一覧を表一6 に示寸．曲げ載荷試験 は，凍結融解試験に用いた 3 体の供試体(PP3-cr) に加え て, 凍結融解を与えずに実験室において水を満たした容 器に水中保管していた 4体の供試体 (以下, 健全供試体) も検討した. 健全供試体は, PP3 繊維を混入した PP3-nd 供試体が 2 体，鋼繊維を混入した Steel-nd 供試体と繊維

表ー6 曲げ載荷試験に用いた供試体一覧

\begin{tabular}{c|c|c|c}
\hline & 供試体数 & 䋊維種類 & \multirow{2}{*}{ 凍結融解作用 } \\
\hline \hline Base2-nd & 1 & なし & \multirow{2}{*}{$\begin{array}{c}\text { なし } \\
\text { (健全供試体) }\end{array}$} \\
\cline { 1 - 2 } Steel-nd & 1 & Steel & \\
\cline { 1 - 2 } PP3-nd & 2 & PP3 & 300サイクル \\
\hline \hline PP3-cr & 3 & PP3 & 300 \\
\hline
\end{tabular}

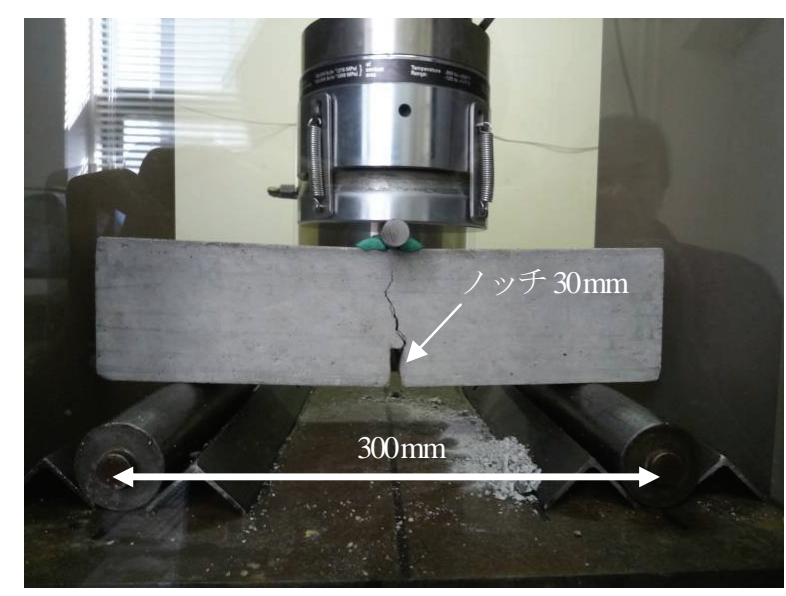

写真－4 曲げ載荷試験 (PP3-nd 供試体)

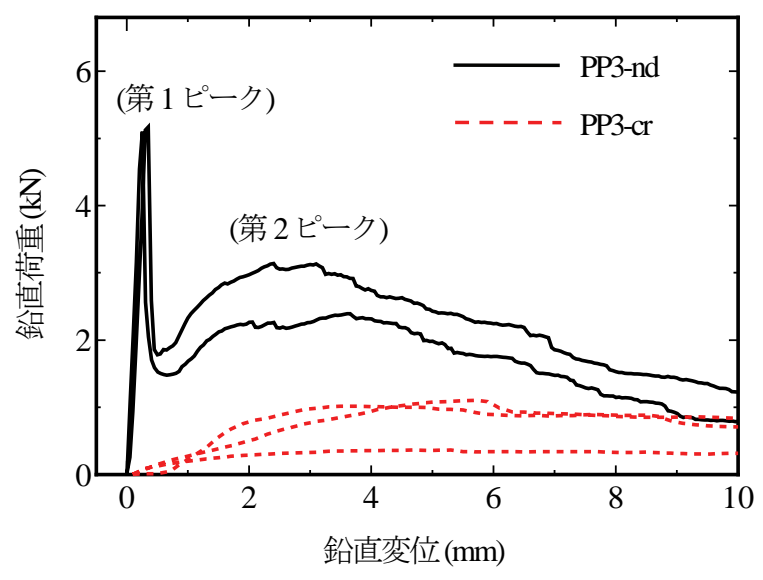

図ー10凍結融解を受けた供試体の曲げ載荷試験 


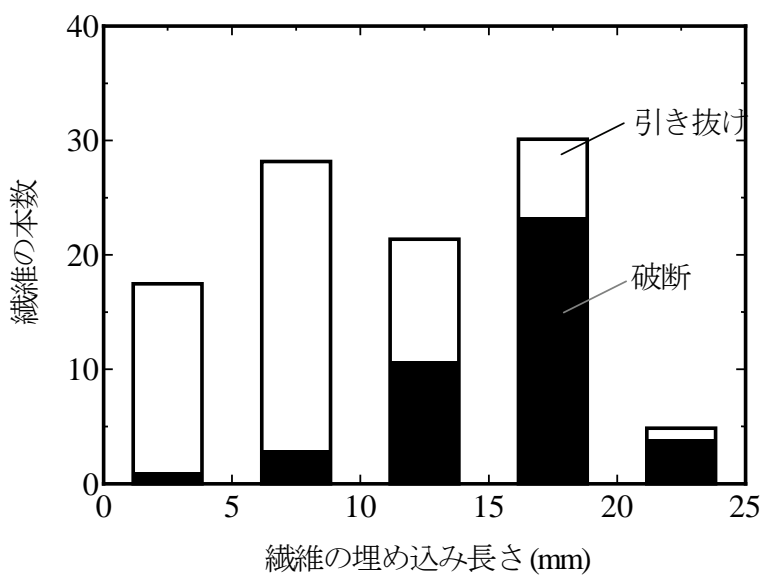

(a) PP3-nd (健全供試体)

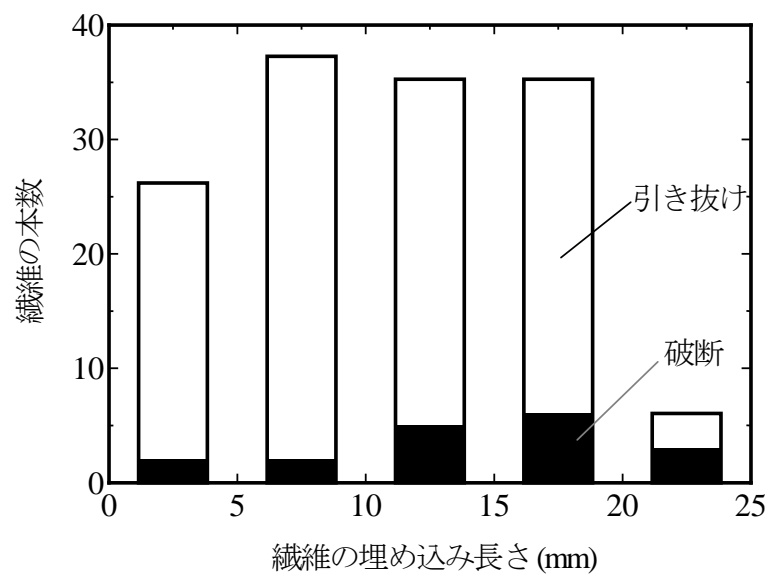

(b) PP3-cr (凍結融解を受けた供試体)

図ー11 繊維の埋め込み長さの分布

\begin{tabular}{|c|c|c|c|c|}
\hline 供試体名 & $\begin{array}{c}\text { 凍結融解 } \\
\text { 作用 }\end{array}$ & $\begin{array}{c}\text { 破断本数 } \\
\text { の割合 }\end{array}$ & $\begin{array}{c}\text { 引抜本数 } \\
\text { の割合 }\end{array}$ & 総本数 \\
\hline PP3-nd-1 & \multirow{2}{*}{ なし } & $35 \%$ & $65 \%$ & 43本 \\
\hline PP3-nd-2 & & $45 \%$ & $55 \%$ & 62本 \\
\hline PP3-cr-1 & \multirow{3}{*}{$\begin{array}{c}300 \\
\text { サイクル }\end{array}$} & $11 \%$ & $89 \%$ & 63本 \\
\hline PP3-cr-2 & & $14 \%$ & $86 \%$ & 36本 \\
\hline PP3-cr-3 & & $15 \%$ & $85 \%$ & 41本 \\
\hline
\end{tabular}

を混入しない Base2-nd 供試体が 1 体ずつである. 供試 体寸法は，凍結融解試験の供試体と同一である．4 体の 健全供試体は，PP3-cr 供試体との統一を図るため，供試 体中央にコンクリートカッターによって $30 \mathrm{~mm}$ のノッ チを導入して曲げ載荷試験を行った。すなわち，健全供 試体の下縁から $30 \mathrm{~mm}$ 区間には，繊維の架橋はない.

曲げ載荷試験では，荷重一変位関係におけるポストピ 一ク挙動を評価するため, 変位制御が可能な超緩速載荷 試験機を用いた. 3 点曲げ載荷試験の載荷状況を写真一 4 に示す. 試験方法は, 支点間距離を $300 \mathrm{~mm}$ とした 3 点曲げ載荷とし，載荷点の荷重と変位を測定した。載荷 速度は載荷点の変位が $0.05 \mathrm{~mm} / \mathrm{s}$ となるように制御した。

b) 荷重一変位関係

凍結融解を受けない健全供試体の荷重一変位関係を図 -9 に示す. 緎維を混入しない Base 2-nd 供試体の荷重一 変位関係では，スパン中央のひび割れ発生に伴って最大 荷重後に急激な荷重低下が見られたが，鋼繊維を混入し た Steel-nd 供試体では, 最大荷重後は徐々に荷重が低下 した.PP3 䋊維を混入した PP3-nd 供試体の荷重一変位関 係では，最大荷重後に Base2-nd 供試体と同様に急激な 荷重低下を示したが，その後，変位の増加とともに荷重

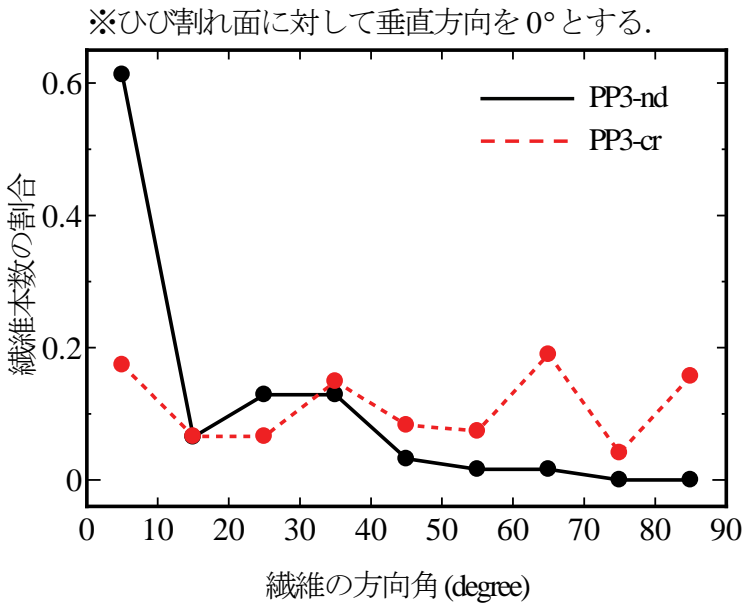

図-12 引き抜けた繊維の方向角の分布

が増加し，鉛直変位 2 $4 \mathrm{~mm}$ 付近 (以下，第 2 ピーク)に おいて再び荷重が緩やかに低下した。このように，鋼繊 維とポリプロピレン繊維による繊維補強コンクリートの 曲げ特性(荷重一変位関係) は大きく異なった。宮崎ら ${ }^{18)}$ は鋼䋊維およびポリプロピレン繊維を用いた䋊維補強モ ルタルの一軸引張試験によって繊維一モルタル間の引抜 特性を検討しており，鋼繊維では最大引抜抵抗時の繊維 のすべり量が $1 \mathrm{~mm}$ 以下であるのに対して, ポリプロピ レン繊維の最大引抜抵抗時の繊維のすべり量は 1.5〜3 mm になることを報告している. すなわち, Steel-nd 供試 体では，供試体に曲げひび割れが発生すると，鋼䋊維は 即時に大きな引抜抵抗力を発揮するため, 荷重一変位関 係では最大荷重後の急激な荷重低下は見られない. 一方, ポリプロピレン繊維は供試体に曲げひび割れが発生して も，ひび割れの開口が小さい範囲では繊維の引抜抵抗力 がほとんど発揮されないため, 無補強コンクリートと同 様に最大荷重後の急激な荷重低下が生じるが，その後は 


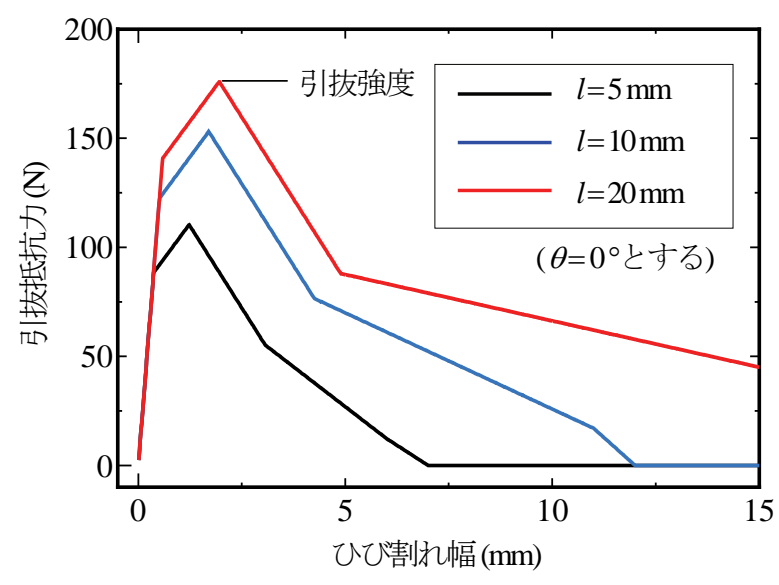

(a) 埋め込み長さlの影響

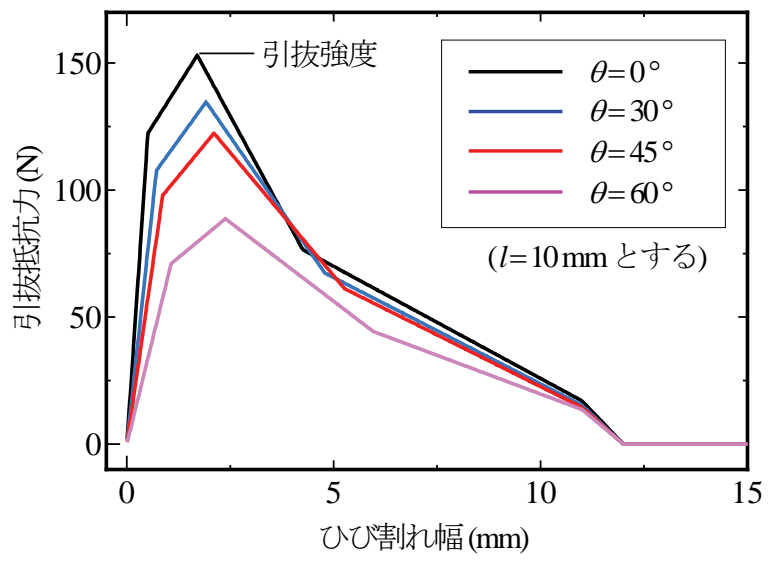

(b) 繊維方向角 $\theta$ の影響

図-13 䋊維単体の引抜抵抗曲線のモデル

繊維のすべり量が 1.5～3 mm になるまで荷重が増加した と考えられる ${ }^{18)}$.

凍結融解試験後の PP3-cr 供試体と凍結融解を受けない 健全供試体 (PP3-nd) の荷重一変位関係の比較を図一10に 示す．健全供試体 (PP3-nd) の最大荷重 (第1ピーク) はコ ンクリートの引張特性に起因するため, 載荷前にひび割 れが貫通している PP3-cr供試体では第 1 ピークは表れな い. さらに, PP3-cr 供試体では第 2 ピークも健全時から 低下している．ひび割れ面に凍結融解が作用することに より，䋊維の引抜特性が低下したと考えられる.

\section{c) ひび割れ面の䋊維の状況}

曲げ載荷試験後に 2 つに分断した試験片の両方のひび 割れ面を目視で観察し, 䋊維の埋め込み長さとひび割れ 面からの角度(以下，䋊維の方向角)を測定した。ここで， 方向角はひび割れ面に対して垂直方向を $0^{\circ}$ として，全 方向から見た傾きの最大值を示す．すなわち，ひび割れ 面と水平に配置される繊維の方向角は 90。である.ただ し, 繊維の埋め込み長さと方向角は，それぞれノギスと 分度器によって測定しているため，その精度については 高くない.

ひび割れ面を跨ぐ PP3 䋊維は, 破断あるいは引き抜け のいずれかに分類される. 目視によって確認された各供 試体の繊維の破断本数と引抜本数を表一7 に示す. 供試 体ごとにひび割れ面を跨ぐ繊維本数は $100 \mathrm{~mm} \times 70 \mathrm{~mm}$ の断面内に 36〜63 本の範囲にあった. ひび割れ面に凍 結融解が作用した PP3-cr 供試体では健全供試体と比較し て，明らかに䋊維の引抜本数の割合が多い. 目視によっ て得た繊維の埋め込み長さおよび方向角の分布をそれぞ れ図-11 および図-12 に示す。これらの図は, PP3-nd 供試体では 2 体，PP3-cr 供試体では 3 体の合計を示した。 なお, 䋊維が破断している場合には，ひび割れ面から繊
維を取り出して埋め込み長さを測定したが，方向角は確 認できなかった. このため, 図一12 の方向角の分布は, 引き抜けた繊維のみの情報である. 図一11より, 䋊維 長 $48 \mathrm{~mm}$ に対して埋め込み長さが 20〜25mm の繊維本 数は少なかったが，0～20 mm までは概ね均等に䋊維が 分布していた. Robins et al. ${ }^{19)}$ は，コンクリート中の鋼繊 維の配向状態を X 線透過撮影による画像解析から明ら かにしており，埋め込み長さは一様分布になることを報 告している. Gasparini et al. ${ }^{20)} も$ 理論的に埋め込み長さは 一様分布になることを指摘している. 図一11より, 凍 結融解を受けない健全供試体 (PP3-nd) では，埋め込み長 の増加に伴って繊維が破断する割合が増加している。一 万，凍結融解を受けた PP3-Crではいずれの埋め込み長さ に対しても繊維が破断する割合は少ない. 後述する繊維 の方向角の影響と, 凍結融解によって繊維とコンクリー トの付着が低下したために，PP3-cr では繊維の破断より も引き抜けが先行したと考えられる.

また，図一12 に示す繊維の方向角の分布より，健全 供試体では，䋊維の多くがひび割れ面に対して垂直方向 に配置されていた. これに対して，アルミ板によって模 擬ひび割れを導入した PP3-cr供試体では，繊維の方向角 に特定の傾向を見出せなかった. なお，ひび割れ供試体 では，打設時に幅 $100 \mathrm{~mm}$ のアルミ板をバイブレータを かけながらコンクリートに埋め込み，さらに木桘を用い て締め固めと打設面の整形を行った. 2 種類の供試体で 異なる䋊維方向角の分布となった理由は，繊維長 $48 \mathrm{~mm}$ に対する型枠形状の関係 ${ }^{19), 21)}$ や打設方法などが考えられ たが，実験データに基づいて明らかにはできなかった.

以降では，破断面の観察によって得られた䋊維の位置， 本数, 埋め込み長さ, 方向角を用いた断面の釣合い計算 によって，纎維の引抜特性を解析的に評価する. 


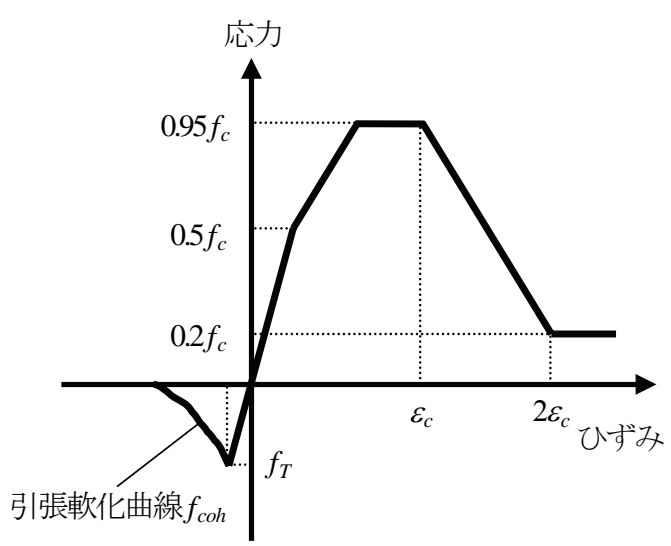

図ー14 コンクリートの応力ーひずみ関係

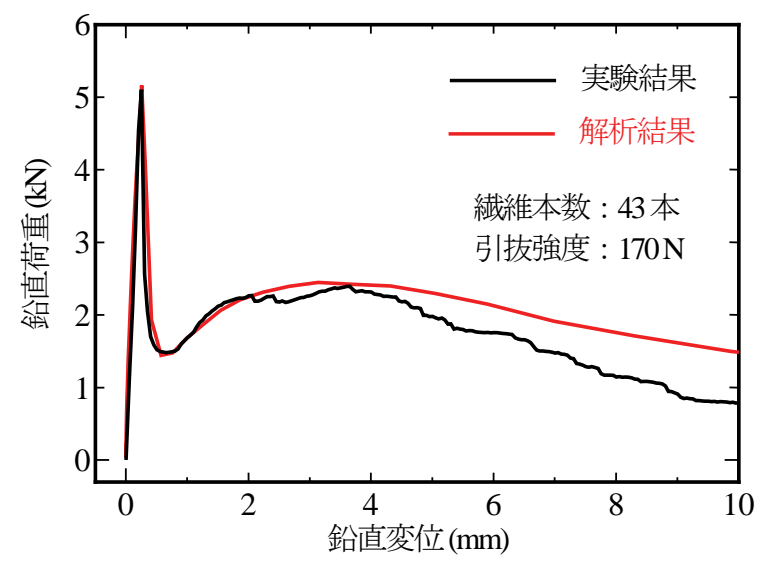

(a) PP3-nd-1 供試体

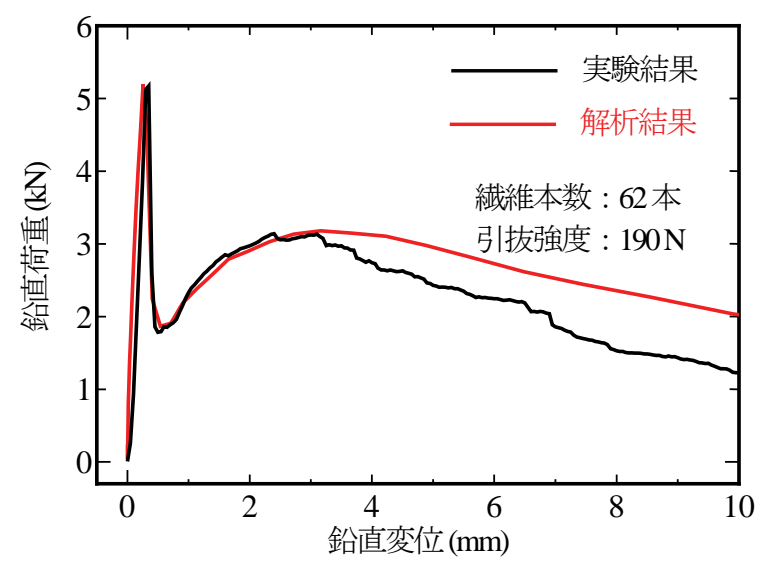

(b) PP3-nd-2 供試体

図-15 健全供試体の再現解析

\section{（3） ポリプロピレン繊維の引抜特性}

\section{a) 解析モデル}

Hugo and Nemkumar ${ }^{22)}$ は繊維の引抜特性を考慮した断 面解析の手法を提示している. この断面解析の中に，i） コンクリートの応力ーひずみ関係，ii)ひび割れ面を跨 ぐ繊維の位置，埋め込み長さおよび方向角， iii)繊維の 引抜抵抗曲線，の3つを組み込むことによって，䋊維補 強コンクリートの曲げ特性を評価する，以降では，曲げ 載荷試験によって得られた荷重一変位関係に整合するよ

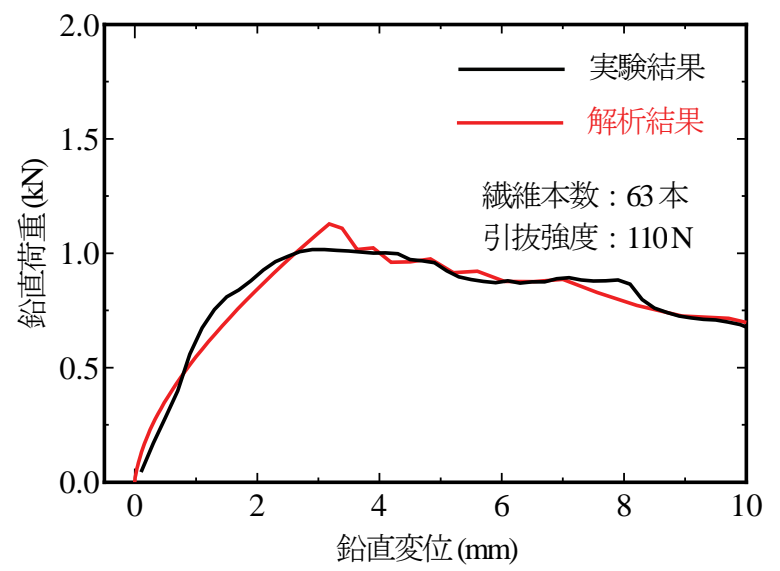

(a) PP3-cr-1 供試体

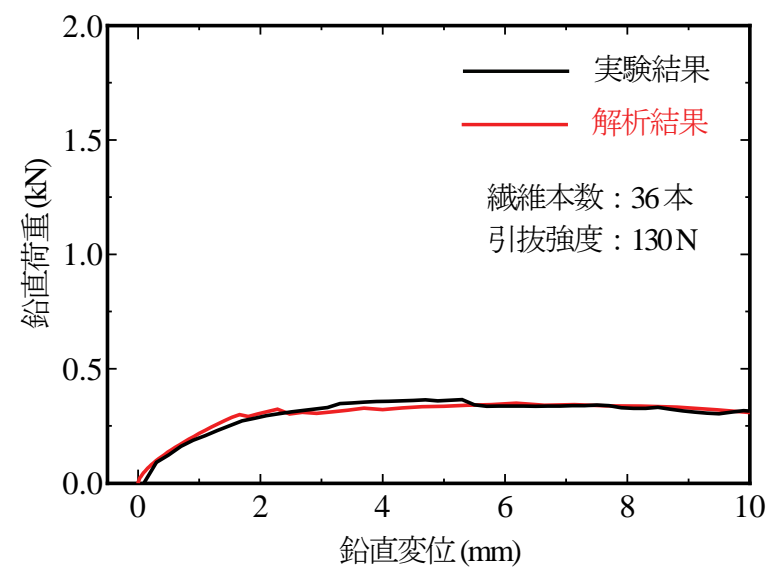

(b) PP3-cr-2 供試体

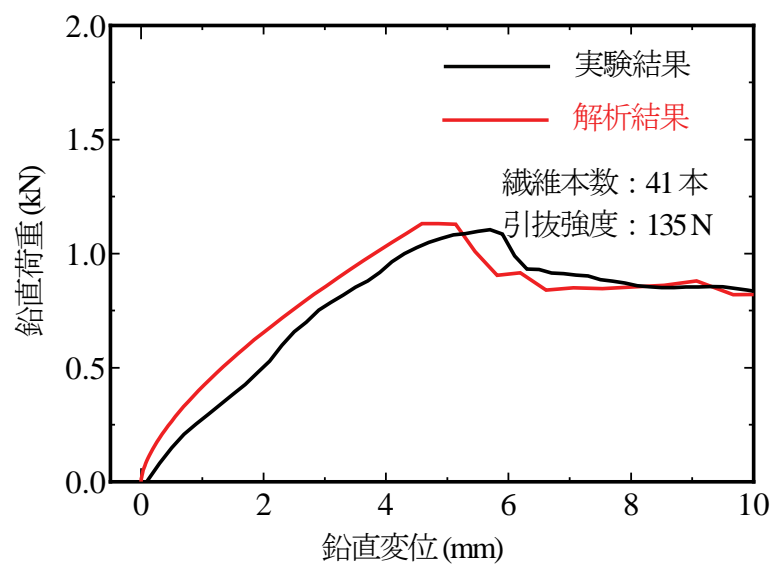

(c) PP3-cr-3 供試体

図ー16 凍結融解を受けた供試体の再現解析

うに PP3 繊維の引抜抵抗曲線を同定する。これによって， 凍結融解による繊維の引抜抵抗力の低下を明らかにする. 曲げ載荷試験後に目視で確認した䋊維の情報を基にし て，断面の釣合い計算により䋊維の引抜抵抗曲線を求め る. 目視による観察では，破断した䋊維の方向角が確認 できなかったため, 図一12 を参考にして，健全供試体

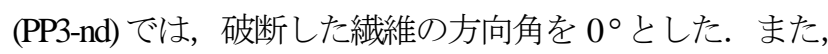
模擬ひび割れを導入した PP3-cr供試体では，繊維方向角 に偏りが見出せなかったため, Robins et al. ${ }^{19)}$ の研究を参 
考にして，破断した䋊維の方向角を $30^{\circ}$ とした. なお， 表一7 に示したように，凍結融解を受けた PP3-c 供試体 において破断した繊維は全体の 1 割程度であるため, 繊 維の方向角の仮定は解析結果に大きく影響しない.

本解析で仮定した繊維単体の引拢抵抗曲線のモデルを 図一13 に示す. 図-13 の引抜抵抗曲線は, 椿ら ${ }^{2324}$ (4) の 手法を参考にして，繊維の埋め込み長さと方向角の影響 を考慮した．椿ら ${ }^{23224)}$ の手法は鋼繊維を想定したモデル であるが，ここでは，既往のポリプロピレン繊維の引抜 抵抗曲線の実験值 ${ }^{18)}$ との整合性を確認しながら, 図一 13 のモデルを使用した。 なお，凍結融解などによって 繊維の引抜特性が変化する場合には，図一13 の解析モ デルの妥当性を検討する必要があるが，ここでは凍結融 解を受けた PP3_cr 供試体に対しても, 図一13 の引拔抵 抗曲線の形状を仮定して解析を行った.

コンクリートの応力ーひずみ関係を図ー14 に示す. 引張域における応力一ひず夕関係は, 一軸引張強度に達 するまでは弾性を仮定した。一軸引張強度に到達後は, Wells and Sluys ${ }^{25}$ や車谷ら ${ }^{26)}$ の研究を参考にして, 式(3) のひび割れの開口に伴う引張軟化曲線を仮定した.

$$
f_{\text {coh }}=f_{T} \exp \left(-\frac{f_{T}}{G_{f}} \cdot w_{i}\right)
$$

ここで， $f_{\text {coh }}$ はひび割れ発生後の結合応力 $(\mathrm{MPa}), f_{T}$ は一 軸引張強度 $(\mathrm{MPa}), G_{f}$ は破壊エネルギー $(\mathrm{N} / \mathrm{mm}), w_{i}$ はひ び割れ幅 $(\mathrm{mm})$ である。これらのパラメータは，図ー9 の健全供試体 Base 2-nd の曲げ載荷試験によって得られ た荷重一変位関係に基づいて定めた。

\section{b) 解析結果}

図一15に健全供試体(PP3-nd) の実験結果と解析結果の 比較を示す. 䋊維補強コンクリートの解析結果は, 第 2 ピークが一致するように図ー13 の繊維の最大引抜抵抗 力 (引抜強度)を与えている. 図中の引抜強度は, 埋め込 み長さ $l=24 \mathrm{~mm}$, 方向角 $\theta=0^{\circ}$ として示した. 第 2 ピー ク以降の実験結果と解析結果が異なるのは, 実験では繊 維の幾つかは破断によって引抜抵抗力が失われるのに対 し, 解析モデルでは繊維の破断を考慮していないためで ある。

凍結融解を受けた PP3-cr 供試体の実験結果と解析結果 の比較を図一16 に示す. これらの解析結果も実験結果 に整合するように繊維の引抜強度を与えた. 図一15 や 図一16 の図中に示すように，健全供試体 (PP3-nd) におけ る繊維単体の引抜強度の平均值が $180 \mathrm{~N}$ であるのに対し て, 凍結融解を受けた PP3-cr供試体の引抜強度の平均值 は $125 \mathrm{~N}$ に低下した。このことから，ひひ割れ面に凍結 融解が作用することにより, 䋊維の引抜強度が健全時と 比較して $70 \%$ 程度まで低下寸ることが示された。

しかし，凍結融解を受けた PP3 繊維は，依然として
繊維単体が $125 \mathrm{~N}$ 程度の引抜抵抗力を有している. これ は，PP3繊維がわずか 1 本でも， $12 \mathrm{~kg}$ 程度のコンクリー ト片の重さに耐えることができる. 寸なわち，表一7に 示した繊維の配置状況や凍結融解による引抜強度の低下 を考慮しても，PP3 繊維を標準量程度混入すれば，コン クリート片の落下防止に対して有用であると考えられる. なお，このような引抜強度の低下は，凍結融解による䋊 維とペーストの界面における摩擦抵抗の低下などによっ て生じると考えられる. 上記は PP3繊維を用いた検討で あり, 䋊維形状や繊維の長さ, あるいは繊維とセメント の材料特性などによって, 引抜強度の低下は異なると予 想される. 今後, 繊維の引抜強度の低下メカニズムを解 明することが課題である.

\section{4. 鉄筋コンクリート}

\section{(1) 実験概要}

上記の検討によって, 繊維長の長いポリプロピレン緎 維は, 凍結融解に伴うコンクリート片の落下防止には有 用であるとの知見を得た。しかし，コンクリート片の落 下を防ぐことができても，コンクリート部材に過大なひ び割れが生じることは耐久性や使用性，あるいは美観上 の観点からも望ましくない. 既往の研究 肪を参照する 限りでは, 鉄筋コンクリート (以下， RC) 構造では, 凍 結融解に伴うひび割れ進展が鉄筋によって抑制されるこ とが予想される，そこで，以降では，模擬ひび割れを導 入した RC 供試体の凍結融解試験を行った.

RC 供試体の諸元を表-1(c)に示す. D6-cr と D 10-cr 供試体では, 断面 $(100 \mathrm{~mm} \times 100 \mathrm{~mm})$ の中心位置に長さ $400 \mathrm{~mm}$ の異形鉄筋 1 本を埋め込んだ. 打設時に鉄筋を 型枠内に固定するため, 型枠の両端には鉄筋径に相当す る孔を空けた厚さ $12 \mathrm{~mm}$ の木製板を設置した. このた め, RC 供試体の長さは $376 \mathrm{~mm}$ である. D6および D 10 鉄筋を使用した際の軸方向鉄筋比は，それぞれ $0.32 \%$ および $0.71 \%$ である.これらの異形鉄筋の材質は SD 345 とした. また，D6 鉄筋を用いた供試体については， 打設面から鉄筋中心位置までの距離を $70 \mathrm{~mm}$ とした供 試体も作製し，かぶりの影響を検討した．RC 供試体の コンクリート配合は，表－2のBase1配合を使用した。

ひび割れの導入および涷結融解試験の方法は, 無補強 コンクリートや繊維補強コンクリートと同様である.

\section{（2）質量減少率および相対動弾性係数}

質量減少率と相対動弹性係数を図-17 と図-18 に示 す.これらは 3 体の平均值として実験結果を示した． D 6-N と D10-N 供試体でも水和による硬化が見られ，300 サイクルまでの質量や相対動弹性係数の低下は小さい. 


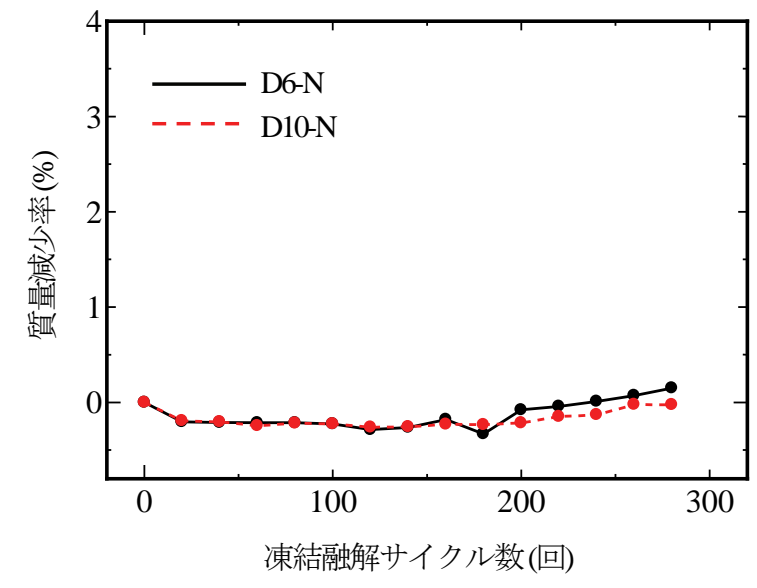

図-17 鉄筋コンクリートの質量減少率

\section{(3) ひび割れ深さ}

式(2) 檤出する際の FEM 解析 ${ }^{13)}$ では, 鉄筋のない無 補強コンクリート供試体を対象とした。一方，同一バッ チのコンクリートによる無筋供試体, D6-N 供試体, D10$\mathrm{N}$ 供試体の 0 サイクル時の共鳴振動数 (縦振動) は, それ ぞれ $4803 \mathrm{~Hz}, 5129 \mathrm{~Hz}, 5216 \mathrm{~Hz}$ であり，鉄筋が共振周波数 に及ぼす影響は小さいと考えられる．また，別途行った 断面中心に D6 鉄筋や D 10 鉄筋を埋め込んだ供試体の FEM 解析の結果でも，ひび割れが鉄筋位置に到達する まで (ひび割れ深さ $d$ が $50 \mathrm{~mm}$ 以下) は，式(2) とこの FEM 解析の結果が良好に一致することを確認した. 図 -19 に示寸 300 サイクまでのひび割れ深さの推定值が いずれも $50 \mathrm{~mm}$ 程度以下であることから，以降では， RC 供試体に対しても式(2)を用いてひび割れ深さを推定 した.

凍結融解サイクル数とひび割れ深さの関係を図ー19 に示す．3種類のひび割れ供試体 (D6-cr, D6-cr(70), D10-cr) の 0 サイクル時のひび割れ深さは 20〜 $30 \mathrm{~mm}$ 程度の範囲 にあり，図一5 や図ー8 に示した無補強コンクリートや 繊維補強コンクリートの場合と比較しても，RC 供試体 のひび割れ深さを良好に推定できた．図一19 より，RC 供試体では，図一5 や図-8 に示した鉄筋のない供試体 とは異なり, 凍結融解に伴うひび割れ進展を大きく抑制 寸ることができた. 力学的なメカニズムを示せる実験デ 一タは得られなかったが，ひび割れ先端部において鉄筋 の引張拘束力が水の凍結膨張圧を上回ったものと考えら れる ${ }^{12)}$. D6 鉄筋を用いた供試体では 300 サイクルまで の凍結融解に対して 10〜 $20 \mathrm{~mm}$ 程度のひび割れの進展 が見られたが，D10 鉄筋を用いた場合にはひび割れの 進展はほとんどなかった. かぶりを $70 \mathrm{~mm}$ とした D6-cr (70)供試体でも，300 サイクルまでのひび割れの進展が 小さいため，D6-cr 供試体との明確な差異は見出せなか った.

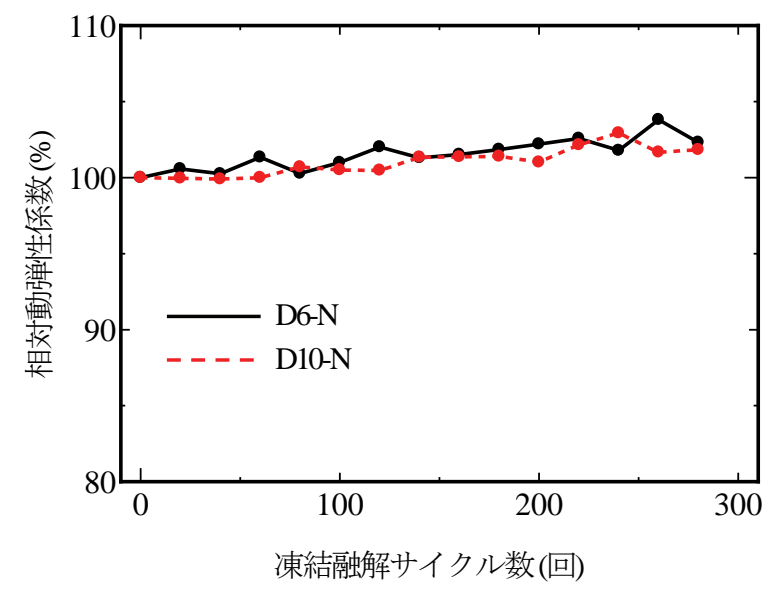

図-18 鉄筋コンクリートの相対動弾性係数

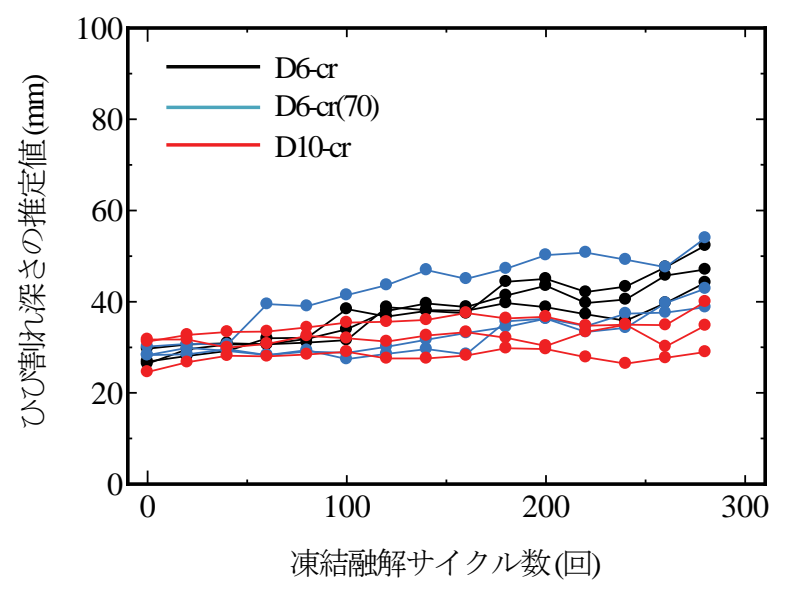

図ー19 鉄筋コンクリートのひび割れ深さ

\section{5. まとめ}

本研究は，模擬ひび割れを導入した無補強コンクリー ト，繊維補強コンクリート，および鉄筋コンクリート供 試体の凍結融解試験を行い, 凍結融解に伴うひび割れ進 展性状に関する基礎的データを収集した. 本検討によっ て得られた知見を以下に列挙する。

1) 材料としては，300 サイクルの凍結融解に対して相 対動弾性係数が低下しない AE コンクリートであっ ても，模擬ひび割れを導入した場合には，凍結融解 に伴ってひび割れが大きく進展することが確認され た．本検討の範囲では，ひび割れ幅 $0.1 \mathrm{~mm}$ やひび 割れ深さ $10 \mathrm{~mm}$ であっても, 300 サイクルまでにひ び割れが供試体を貫通寸る事例が確認された.

2) 本実験で用いた 3 種類のポリプロピレン繊維と 1 種 類の鋼繊維では, 凍結融解によるひひ割れ進展を効 果的に抑制することはできなかった。しかし，繊維 長の長いポリプロピレン繊維 (PP3 繊維) を使用した 場合には，凍結融解によるひび割れの開口に対して 
も繊維の架橋が保たれており，ひび割れ面にはコン クリート片の自重に耐える引抜抵抗力が存在した.

3）凍結融解試験後の供試体を用いた曲げ載荷試験と解 析的検討によって, PP3 䋊維単体の引抜強度を同定 した．凍結融解を与えない健全状態では PP3 䋊維の 引抜強度が $180 \mathrm{~N}$ 程度であったが，300 サイクルの 凍結融解を受けることによって，繊維単体の引抜強 度は健全時の約 $70 \%(125 \mathrm{~N})$ まで低下した。しかし， 凍結融解による引抜強度の低下を勘案しても，PP3 纎維はコンクリート片の落下防止に対して有用であ ると考えられる.

4) D6および D10 鉄筋を埋め込んだ鉄筋コンクリート 供試体の検討では，鉄筋の拘束によって凍結融解に 伴うひび割れの進展を大きく抑制することができた. 特に，D10 鉄筋を用いた供試体では，300 サイクル の凍結融解に対してもひび割れの進展がほとんど見 られなかった。

以上より， RC 部材であれば鉄筋の拘束によって凍結 融解に伴うひび割れの進展が抑制できる可能性が示唆さ れた. 一方，鉄筋のない無筋コンクリート構造などでは, 材料としては優れた凍結融解抵抗性を有していても，ひ び割れ部に水が浸入した場合に，凍結融解に伴ってひび 割れが進展する可能性が示された. 無筋コンクリート構 造や鉄筋の拘束が十分に期待できない箇所においてコン クリート片の落下を防止するためには，䋊維長の長いポ リプロピレン繊維を使用することも対策のひとつと考え られる。

なお，本検討では，限られた供試体の本数と諸元，お よび実験条件によって上記の結論を得た．凍結融解に伴 うひび割れ進展性状に関する実験結果は，供試体ごとに 大きくばらつくことから, 今後, 供試体の本数を増やす ことや，損傷の与え方を変えた検討も必要である．また， 本実験の鉄筋コンクリート供試体では，ひび割れの進展 が鉄筋位置に及んでいるものが見られた。凍結融解を受 ける RC 部材でのひび割れ進展性状や，ひび割れが鉄筋 に到達した後のかぶりの剥落，鉄筋とコンクリートとの 付着劣化など，凍害による RC 部材の力学的性能の低下 については不明な点が多い. 様々な寸法や形状のコンク リート部材についても検討し，ひび割れの開口と拘束条 件, 部材の力学的性能に及ぼす影響を整理することが課 題である.

\section{参考文献}

1) 山洞晃一：寒冷地におけるコンクリート構造物の長 期耐久性向上, 日本鉄道施設協会誌, Vol. 47, pp. 56-58, 2009.

2) 土木学会 : コンクリート標準示方書 設計編, 2007.

3) 日本コンクリート工学協会 東北支部: 東北地方にお
けるコンクリート構造物の凍害に関する調查研究委 員会報告書, 2001 .

4) 橋口大輔, 添田政司, 大和竹史：初期に導入したひ び割れがコンクリートの耐久性へ及ぼす影響に関す る研究, コンクリート工学年次論文集, Vol. 26, No. 1, pp. 729-734, 2004.

5) 今村和也, 添田政司, 大和竹史 : 凍害, 塩害, 中性 化に及ぼす初期ひび割れの影響に関する一考察, 土 木学会第 57 回年次学術講演会, 5-669, pp. 1337-1338, 2002.

6) 杉木六郎：鉄筋コンクリートポールおよびくいに用 いるコンクリートの施工方法に関する研究, 土木学 会論文集, No. 88, pp. 29-49, 1962.

7) 田畑雅幸, 洪悦郎, 鎌田英治：コンクリートの凍害 におけるひび割れの役割の考察, 日本建築学会構造 系論文報告集，No. 366，pp. 11-17，1986.

8) 細田暁, 菅野貴浩, 石橋忠良 : 合成短繊維添加によ るコンクリート片の剥落対策, コンクリート工学年 次論文集, Vol. 25, No. 1, pp. 275-280， 2003.

9) 大島章弘, 矢吹増男, 坂田昇, 古市耕輔, 平石剛 紀 : 連糸状ポリプロピレン䋊維を用いたコンクリー 卜の剥落防止技術の開発, 土木学会第 59 回年次学術 講演会，5-512, pp. 1021-1022, 2004.

10) 平石剛紀, 坂田昇, 林大介, 山村正人: 剥落防止を 目的とした有機系繊維補強コンクリートに関する研 究, コンクリート工学年次論文集, Vol. 23, No. 1, pp. 469-474, 2001.

11) 矢吹増男, 俣野作男, 平石剛紀, 坂田昇: 波形ポリ プロピレン繊維を用いたコンクリートの剥落防止技 術の開発，土木学会第 56 会年次学術講演会，V-589, pp. 1178-1179, 2001.

12) 内藤英樹, 山洞晃一, 古賀秀幸, 鈴木基行 : 初期ひ び割れを有するコンクリートの凍結融解抵抗性，コ ンクリート工学年次論文集, Vol. 30, No. 1, pp. 915-920, 2008.

13) 内藤英樹, 山洞晃一, 古賀秀幸, 鈴木基行 : 初期ひ び割れを有する繊維補強コンクリートの凍結融解試 験, コンクリート工学年次論文集, Vol. 31, No. 1, pp. 1135-1140, 2009.

14) 内藤英樹, 山洞晃一, 古賀秀幸, 鈴木基行 : 凍結融 解作用を受けた繊維補強コンクリートの引張特性, コンクリート工学年次論文集, Vol. 32, No. 1, pp. 863-868, 2010.

15) 鉄道総合技術研究所: 鉄道構造物設計標準 - 同解説 コンクリート構造物, 2004.

16) 土木学会 : コンクリート標準示方書 規準編, 2005.

17）林弘, 内藤英樹, 鈴木基行, 齊木佑介, 山洞晃一, 古賀秀幸 : 共鳴振動試験によるコンクリートのひび 割れ深さの推定, 土木学会第 64 回年次学術講演会, V-214, pp. 425-426, 2009.

18）宮崎晋行, 大久保誠介, 福井勝則：コンクリート補 強用 PET 繊維とポリプロピレン繊維の引抜特性, 資 源と素材，Vol. 121，pp. 363-369， 2005.

19) Robins, P. J., Austin, S. A. and Jones, P. A.: Spatial distribution of steel fibres in sprayed and cast concrete, Magazine of Concrete Research, Vol. 55, No. 3, pp. 225235, 2003.

20) Gasparini, D. A., Verma, D. and Abdallah, A.: Postcracking Tensile Strength of Fiber Reinforced 
Concrete, ACI Materials Journal, Vol. 86, No. 1, pp. 10-15, 1989.

21）馬場弘二，伊藤哲男，松本健次，鳥越信一，吉武勇, 中川浩二 : コンクリート中におけるプラスチック系 繊維の配向状態の評価方法，土木学会論文集，No. 760/V-63, pp. 173-180, 2004.

22) Hugo, S. A. and Nemkumar, B.: Predicting the Flexural Postcracking Performance of Steel Fiber Reinforced Concrete from Pullout of Single Fibers, ACI Materials Journal, Vol. 94, No. 1, pp. 18-31, 1997.

23）椿龍哉, 荒井和久, Sunaryo Sumitro：鋼繊維補強コン クリートの一軸引張およびせん断に対する力学特性 に及ぼす繊維特性の影響, コンクリート工学論文集， Vol. 10, No. 2, pp. 109-118, 1999.
24）椿龍哉, 荒井和久, 保永武徳 : 鋼繊維補強コンクリ 一トの一軸引張およびせん断に対する変形挙動のモ デル化，コンクリート工学論文集, Vol. 11, No. 3, pp. 29-38, 2000.

25) Wells, G. N. and Sluys, L. J.: Application of embedded discontinuities for softening solids, Engineering Fracture Mechanics, Vol. 65, pp. 263-281, 2000.

26）車谷麻緒, 湯本達也, 寺田賢二郎, 秋山充良 : エネ ルギー収支に基づくコンクリートの破壊勒性評価法 に関する基礎的研究，コンクリート工学年次論文集， Vol. 31, No. 2, pp.97-102, 2009.

\section{FREEZING AND THAWING RESISTANCE OF CONCRETE WITH INITIAL CRACK}

\section{Hideki NAITO, Hiroshi HAYASHI, Yusuke SAIKI, Koichi SANDO, Hideyuki KOGA and Motoyuki SUZUKI}

Freezing and thawing resistance of concrete with an initial crack was investigated. The specimens were classified into plane concrete, fiber reinforced concrete, and reinforced concrete. In the tests of plane concrete with an initial crack, the crack grows seriously by the frozen expansion pressure of the water infiltrated into the crack, though the concrete material had high resistance to freezing and thawing. In the experimental results of fiber reinforced concrete, the long polypropylene fiber was useful to prevent the spalling of concrete cover, though the crack growth was not prevented. Moreover, in the experimental results of reinforced concrfete, it was shown that the crack growth was effectively prevented by steel reinforcing bar. 